\title{
The Seasonal Abundance and Distribution of the Pelagic Young of Teleostean Fishes Caught in the Ring-trawl in Offshore Waters in the Plymouth Area. Part II.
}

\author{
By
}

F. S. Russell,

Naturalist at the Plymouth Laboratory.

With 8 Figures in the Text.

A REPORT was published in 1930 on the seasonal abundance of young fish in the plankton covering the years 1924 to 1929 (Russell, 1930, b). On concluding that report it was thought that for several reasons it would be worth while continuing the routine weekly collections on the standard basis of half-hour oblique hauls with the 2-metre stramin ring-trawl for a further period of years.

During the compilation of the 1930 report there was a constant desire to know what the composition and abundance of the young fish fauna might have been in past years, but no data of a sufficiently quantitative and comparable nature were available. The 1930 report was based on a series of collections not all of which had been taken in the same way, and in no year were collections made continuously throughout the twelve months. It was therefore thought advisable that a series of collections all made in the same way should be obtained regularly through the twelve months for a number of years in succession. Thus there would be formed a standard set of data to act as a basis for comparison for those who may come after. It is only by such methods that it will be possible to observe faunistic changes over a very long period of years.

We want also to know to what extent a planktonic population of young fishes comprising some fifty or more species varies in its proportional composition from year to year. It was thought that in a population of so many species of fishes there would be found evidence of those violent fluctuations in abundance that bring about the well-known good and bad survival years which so vitally affect the composition of our food-fish stock. In the event of such fluctuations appearing it would be interestng to observe whether a good or bad year for one species of fish held good also for certain other species whose young occurred in the plankton at the same time of the year. Under such circumstances if a number of 
species were affected in the same way in one year it might be found possible to obtain indications of some of the causes of fluctuations.

The collections, 220 in all, were made (with 4 exceptions, see footnotes to Table III) at a position 2 miles east of the Eddystone lighthouse in water of a depth of about 54 metres. They are therefore indicative of offshore conditions. For a work of this nature to be complete it is necessary to know the spawning areas of the different species of fish; unfortunately our knowledge is largely lacking in this respect. It is thought, however, that even if the centre of a spawning area is situated at some distance, an increase or decrease in abundance would show itself in outlying regions among those species whose pelagic young normally occur in the waters off Plymouth. It must, however, always be borne in mind that a change in abundance thus shown may be produced by a shifting of the normal spawning area. But when the young of any species are present normally in large numbers there is some justification for believing that a large body of adult fish must have been spawning in waters at no great distance from Plymouth, or at any rate that the spawning area is so situated that it is normal for a large number of the fry produced to drift past in our offshore waters.

The collections were made in the stramin ring-trawl (diameter at mouth, 2 metres; length, 6 metres; stramin obtained from Messrs. N. P. Utzon, Copenhagen, $c a$. 16 strands to one inch) by means of oblique hauls. A description of the method of working has already been given (Russell, 1930, a, p. 640) the net being first fished at the surface and then in successive steps with $10,20,35,45$ and 60 fathoms of wire out respectively, so that the net was in the water for half an hour. The net was fished on the warp used for the otter trawl and collections were made by the crew of S.S. Salpa under the supervision of Capt. V. Lord. As nearly as possible the collections were taken at weekly intervals, and they cover the years 1930 to 1934 inclusive.

It may be thought that material obtained by only a single collection each week is insufficient to base conclusions on ; the results have on the whole, however, shown such consistency that they seem to prove their own reliability.

In collections of this sort weather conditions under which the work is undertaken should be considered. There is of course a limit in wind and sea conditions beyond which it is impracticable to work the gear. A few of the collections have, however, been made under conditions when it was found necessary to use a four-inch dredge-rope, rather than the wire trawl warp, for fear of the sudden jerks on the less elastic wire straining unduly the meshes of the stramin. Since collections were made in weather conditions up to this limit, the relations between the size of the catches and the wind force under which they were obtained have been 
examined. It was, however, found that just as large catches were likely to be taken on rough days as on calm and that on the whole weather conditions were not likely to have upset the true picture of the results. It is only natural that whenever possible the most suitable days were chosen for collecting.

The data obtained are here given in a similar manner to that adopted in the previous report. The average catches per half-hour haul for each month in each year of all fishes combined and of the post-larvæ of each species are given in Table IV* on page 176. Byadding these averages for any one month and dividing by the number of years in which collections were made in that month an average monthly catch was obtained for the period of the five years 1930 to 1934 inclusive. These average catches are given in Table I. In the last two columns of Table I are also given the sums of these average monthly catches for 1930 to 1934, and for 1924 to 1929 from Table I, page 712, of the 1930 report.

The dates in each year on which the collections were made are given in Table III on page 175 .

\section{General Results.}

In considering the data obtained it is firstly of interest to gain an idea of the general picture of the abundance at different times of the year of all species of fish combined. In doing this the Clupeids have been excluded owing to the possibility that daylight figures do not give a true picture of their abundance (Russell, 1930, a, p. 649), and also because on account of the shoaling habits of the spawning fish the results are occasionally distorted by the occurrence of large numbers of newly hatched larvæin the plankton. Accordingly in Table IV(p.176), besides the average monthly catches in each year of all fish combined, corresponding figures are also given for all fish excluding Clupeids. By adding together the average monthly catches of the latter and dividing by the number of years, average figures can be obtained for the five-year period, 1930 to 1934, which give a mean picture of the seasonal occurrence and abundance of the fish in the collections. But there is a possibility that by grouping the catches into calendar months a slightly distorted picture of the true sequence of events might be produced if at any time the greatest catches of fish appeared either near to the beginning or the end of a month. The months have accordingly been subdivided into fortnightly periods, so that those catches falling on the 1st to the 15th day of the month inclusive have been included in the first fortnight and those on the 16th to the last day of the month in the second fortnight. The data so obtained have been plotted in the form of a graph in Figure 1. The curve shows clearly that the maximum abundance of young fish may be expected

\footnotetext{
* In this table when the average for the month is less than $0.5 \mathrm{a}+$ has been inserted.
} 
to occur during the period between the second fortnight in April and the first fortnight in June. In June the numbers in the catches fall off considerably and a period of low productivity lasts from then until the first fortnight in September, after which the young fish almost die out

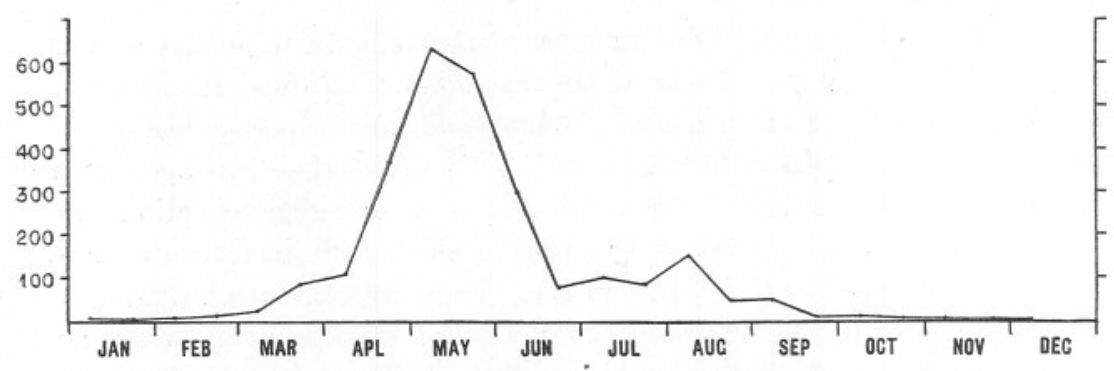

Frg. 1.-Curve showing the average eatches in half-hour oblique hauls with the 2-metre ring-trawl for each fortnight for all young fish, excluding Clupeids, averaged over the whole period 1930 to 1934 inclusive.

from the collections. This curve in Figure 1 may be regarded as a type of mean seasonal distribution to be used as a standard with which the distributions in any individual year may be compared. That this may be regarded as a reliable mean gains support from a comparison with the results obtained during the previous period, 1924 to 1929 . The curves

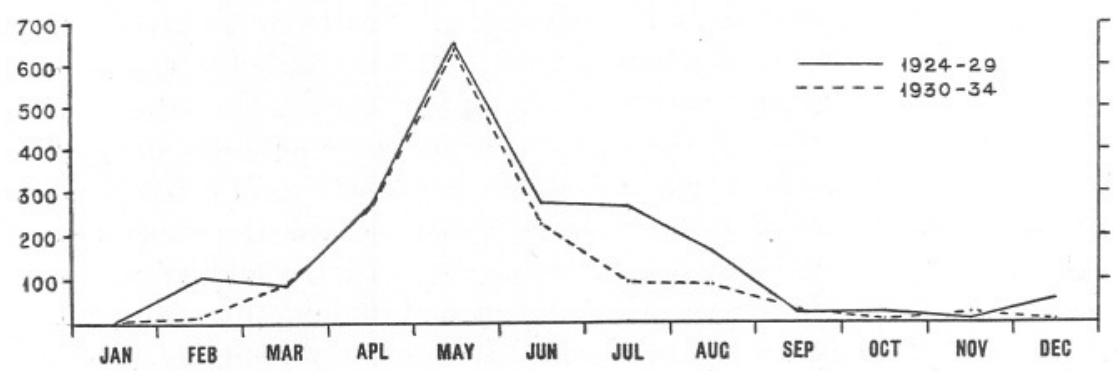

FIG. 2.-Curves showing the average monthly catches in half-hour oblique hauls with the 2 -metre ring-trawl for all young fish, excluding Clupeids, for the two periods 1924 to 1929 , and 1930 to 1934 inclusive.

for the average monthly catches for the two periods 1924-29 and 1930-34 have been drawn in Figure 2. The agreement between these two curves is remarkably close, the only anomalies being in February, which month in the former period is based on collections in one year only (1928) when there was a heavy eatch of very small Ammodytes post-larvæ, and in July and August when the 1924-29 totals appear to have been significantly higher than those for 1930-34 (see p. 169). 


\section{The Seasonal Composition of the Catches.}

Before proceeding with a comparison of the individual years, it will be well to analyse the curve in Figure 1 to find out what species are responsible for the general shape of the curve and how the composition of the catches varies with the time of year. In the previous report (1930, p. 711) a table is given showing the months in which the maximum abundance of the post-larvæ of each species may be expected on the average. The results in Table I, p. 712, of the 1930 report have been combined with those given in Table I of this report, and a new table has been produced showing the months in which each species may be expected to occur in maximal abundance averaged over the eleven years, Table II. When examining this table it should be remembered that when two fish fall in the same month their actual seasonal distribution may be slightly different, one species having a bias towards the previous month and the other to the succeeding month. Table I should therefore be used in conjunction with Table II as it gives a truer picture of the average seasonal distribution. When a species only occurs in very small numbers over a number of months the month in which the greatest numbers have been taken on the whole period has generally been chosen for insertion in Table II. In constructing this table an attempt has also been made to assign each species to its geographical area. Divisions have been made on the basis of Hjort's data (1910, p. 442 et seq.) in which he has divided fish into northern and southern species. In making this division one has to realise that the distinction is not one of latitude only but that the distribution of the temperature of the water must also be taken into consideration. In Table II Hjort's northern species have been designated boreal, and these speciès have been further subdivided into those whose distribution tends towards arctic-boreal regions, those which are centred about the North Sea, and those species whose distribution tends towards the waters of the south-west of the British Isles. These three divisions are indicated in Table II by the letters N, B, and S respectively after the names of the fish. Hjort's southern species are here regarded as warmwater species, and these have again been further subdivided into those species whose centre of distribution tends towards the northerly boundary south-west of the British Isles and follows the warm water up the west coasts of the British Isles, and those which tend to be even more southerly in character. These last two divisions are indicated by the italicised letters $N$ and $S$ respectively after the names of the fish in question. The two main divisions, boreal and warm water, are also indicated in Table II by printing the boreal species in roman type and the warm-water species in italics. Some difficulty was experienced in assigning the different fish to their respective areas, since it is their abundance in different localities 
TABLE I.

Average Monthly Catches of Post-larvæ per Half-hour Oblique Haul with 2-Metre Ring-Trawl, 1930-1934.

Clupeid spp.*

Gadus pollachius

Gadus merlangus

Gadus minutus

Gadus luscus

Gadus callarius

Onos spp. $\dagger$

Molva molva

Merluccius merluccius

Raniceps raninus

Capros aper

Zeus faber

Arnoglossus spp. $\neq$

Rhombus lævis

Rhombus maximus

Scophthalmus norvegicus

Scophthalmus unimaculatus

Zeugopterus punctatus

Pleuronectes limanda

Pleuronectes flesus

Pleuronectes microcephalus

Solea vulgaris

Solea variegata

Solea lascaris

Serranus cabrilla

Caranx trachurus

Mullus surmulletus

Morone labrax

Ammodytes tobianus**

Ammodytes lanceolatus

Jan. Feb. March. April. May. June. July. Aug. Sept. Oct. Nov. Dec.

Totals.

$\begin{array}{rrrrrrrrrrrrrr}72 & 227 & 491 & 87 & 56 & 35 & 23 & 25 & 14 & 72 & 16 & 4 & 1122 & 379 \\ - & - & + & 2 & 10 & + & - & - & - & - & - & - & 12 & 11 \\ - & - & 2 & 65 & 109 & 19 & 1 & + & - & - & - & - & 196 & 131 \\ - & 2 & 40 & 28 & 25 & + & - & - & - & - & - & - & 95 & 124 \\ 4 & 3 & 2 & 2 & 3 & + & + & 1 & - & 2 & 4 & 1 & 22 & 82 \\ - & + & + & + & - & - & - & - & - & - & - & - & + & 1 \\ - & - & 1 & 16 & 30 & 5 & + & - & - & + & + & - & 52 & 30 \\ - & - & - & - & 1 & 1 & - & - & - & - & - & - & 2 & 8 \\ - & - & - & - & - & + & - & + & + & + & - & - & + & 3 \\ - & - & - & - & - & - & + & + & - & + & - & - & + & + \\ - & - & - & - & - & - & + & + & + & - & - & - & + & 1 \\ - & - & - & - & - & - & - & + & + & + & - & - & + & + \\ - & - & - & - & - & 1 & 4 & 10 & 17 & 1 & + & - & 33 & 33 \\ - & - & - & + & + & + & + & + & + & - & - & - & + & 1 \\ - & - & - & - & - & + & + & 1 & + & - & - & - & 5 \\ - & - & + & 8 & 32 & 17 & 2 & + & - & - & - & - & 59 & 60 \\ - & - & - & - & - & - & - & - & - & - & - & - & - & + \\ - & - & - & 2 & 3 & 1 & - & - & - & - & - & - & 6 & 9 \\ - & - & 3 & 17 & 40 & 5 & - & - & - & - & - & - & 55 & 83 \\ - & - & 1 & 2 & 2 & + & - & - & - & - & - & - & 5 & 6 \\ - & - & 1 & 1 & 15 & 6 & + & - & - & - & - & - & 23 & 33 \\ - & - & 1 & 2 & 2 & + & - & - & - & - & - & - & 5 & 6 \\ - & - & + & 13 & 45 & 24 & 1 & + & - & - & - & - & 83 & 79 \\ - & - & - & - & - & - & + & + & + & + & - & - & + & 1 \\ - & - & - & - & - & - & - & + & 1 & - & - & - & 1 & 1 \\ - & - & - & - & - & - & 1 & 8 & 5 & + & - & - & 14 & 44 \\ - & - & - & - & - & - & + & + & - & - & - & - & + & + \\ - & - & + & + & + & - & - & - & - & - & - & - & + & + \\ 2 & 4 & 19 & 2 & + & + & + & + & + & + & - & - & 27 & 116 \\ 1 & + & + & 4 & 9 & 4 & 2 & 4 & + & + & - & - & 24 & 57\end{array}$


Cepola rubescens

Callionymus spp.§

Labrus bergylta.

Labrus mixtus

Ctenolabrus rupestris

Crenilabrus melops

Centrolabrus exoletus

Trachinus vipera

Trachinus draco

Scomber scombrus

Gobiid spp.

Lebetus scorpioides

Blennius pholis

Blennius ocellari

Blennius gattorugine

Chirolophis galerita

Agonus cataphractus

Trigla spp. -

Cottus bubalis

Liparis montagui

Lepadogaster bimaculatus

Lophius piscatorius

$\begin{array}{lll}- & - & - \\ - & + & 11 \\ - & - & - \\ - & - & - \\ - & - & - \\ - & - & - \\ - & - & - \\ - & - & - \\ - & - & - \\ - & - & - \\ + & + & + \\ - & - & - \\ - & - & - \\ - & - & - \\ - & - & - \\ + & 2 & 5 \\ - & - & - \\ - & - & - \\ - & + & 3 \\ - & - & + \\ - & - & + \\ - & - & +\end{array}$

\begin{tabular}{cc}
$\overline{76}$ & $30 \overline{1}$ \\
- & 1 \\
- & + \\
- & - \\
- & - \\
- & - \\
- & - \\
- & - \\
- & - \\
+ & 3 \\
- & - \\
- & + \\
- & - \\
- & + \\
+ & - \\
+ & - \\
1 & 5 \\
2 & 1 \\
+ & + \\
$\overline{1}$ & + \\
\hline & -
\end{tabular}

104
2
1
1
+
-
-
-
10
6
+
-
-
+
-
-
3
-
+
-
+

All young fish

$\begin{array}{lll}78 & 238 & 582\end{array}$

329

696

259

-
+8
+
-
9
1
1
3
-
9
15
+
+
+
9
-
-
3
-
-
+
1

+
22
-
-
4
+
+
4
+
3
19
1
+
2
3
-
-
3
-
-
1
-

\begin{tabular}{|c|c|c|c|c|c|}
\hline+ & - & - & - & + & 1 \\
\hline 2 & 3 & 1 & + & 548 & 965 \\
\hline - & - & - & - & 3 & 12 \\
\hline - & - & - & - & 1 & 8 \\
\hline+ & - & - & - & 14 & 20 \\
\hline - & - & - & - & 1 & 6 \\
\hline - & - & - & - & 1 & 4 \\
\hline+ & - & - & - & 7 & 22 \\
\hline - & - & - & - & + & + \\
\hline+ & - & - & - & 22 & $29 \dagger \dagger$ \\
\hline+ & + & + & + & 43 & 145 \\
\hline 1 & + & - & - & 2 & 16 \\
\hline $\bar{j}$ & - & $\overline{-}$ & - & + & 2 \\
\hline $\begin{array}{l}1 \\
+\end{array}$ & _- & - & - & 3 & 1 \\
\hline- & - & - & - & $\begin{array}{r}12 \\
7\end{array}$ & $\begin{array}{r}15 \\
6\end{array}$ \\
\hline - & - & - & - & + & 1 \\
\hline 1 & + & - & - & 16 & 41 \\
\hline - & - & - & - & 6 & 8 \\
\hline+ & - & - & - & + & 3 \\
\hline+ & - & - & - & 1 & 6 \\
\hline - & - & - & - & 2 & 2 \\
\hline 43 & 79 & 21 & 6 & 2559 & 2256 \\
\hline 29 & 7 & 6 & 1 & 1437 & 1867 \\
\hline
\end{tabular}

* Includes Clupea harengus, C. sprattus, and C. pilchardus.

$\dagger$ Includes mostly Onos mustela and $O$. tricirratus.

Includes probably mostly Arnoglossus laterna and a few A. imperialis and $A$, thori.

Mostly Callionymus lyra in the spring, and some $C$. maculatus in summer.

Includes Trigla gurnardus, T. hirundo, T. cuculus, and T. lineata.

$\dagger$ Excluding 1926.

* The identification of Ammodytes post-larvæ is uncertain now that Raitt (1934) has raised a new species, A. marinus. 
TABLE II.

Months in which Post-Larva of Different Species may be most abundant in the Ring-trawl Catches.

(N., northern boreal; B., Boreal; S., southern boreal; N., northern warm water ; S., southern warm water. Boreal spaces are printed in roman type: warm water species in italics.)

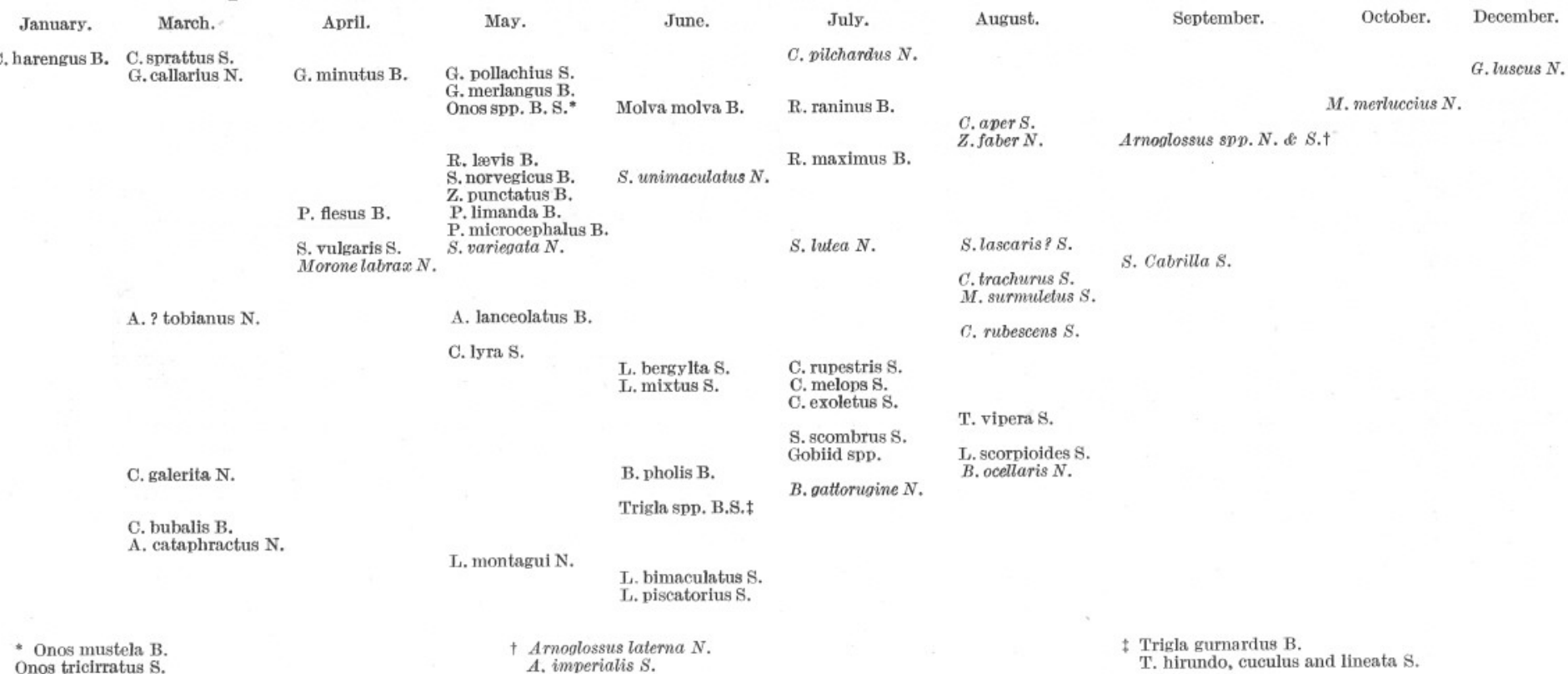


rather than the extreme known limits of their distribution that is of importance here. Hjort (1910, pp. 441-442) has given tables showing the percentage landed in each area of the total quantity landed for a number of species of food fishes; it is really this type of information that is required, and this is naturally not available for non-commerical species. The geographical distributions indicated in Table II must not therefore be regarded as final; in the main, however, it is probable that they are correct.

This table shows the general tendency for the colder-water species to appear earlier in the year and then their gradual giving way to warmerwater species which predominate in the summer months. But while there is this general sequence there is not strict adherence to the rule, since we may find southern boreal species appearing before northern boreal ones, and northern warm-water species before boreal forms. If, however, we examine closely-related species we find that the sequence is more strictly adhered to. The position of the Clupeids and of the soles, for instance, is distinctly early compared with the main body of species; yet the most northerly species of the Clupeids, the herring, occurs before the sprat, and the latter before the pilchard. Similarly Solea vulgaris, S. variegata, and $S$. lutea and S. lascaris follow one another in accordance with their geographical distribution from north to south. We thus see that among all species taken together there is, as we should expect, variation in time of abundance, i.e. all boreal species do not appear together and so on. But when we confine ourselves to nearly related species, the season of abundance of one species considered in relation to that of another is an indication of their relative geographical distributions. Schmidt has drawn attention to this fact for Gadoids (1909, pp. 154-155), and also species of Agonus and Cottus. An apparent exception to this rule may be found in the turbot, $R$. maximus, and the brill, $R$. lavvis. Of these two the brill has perhaps the more southerly distribution, but breeds first. The turbot, however, is a rather deeper-water fish.

Tables I and II thus show us the composition of the young fish fauna at different times of the year which combine to produce the general curve of seasonal distribution given in Figure 1.

Comparison of this figure and the tables shows that although there are no more species appearing in the spring than in the summer, yet during the period April to June there are very many more young fish than in the later months. It will be of interest to see which species of fish produce this noticeable peak in the curve in the spring months. Accordingly the proportions of the more important species expressed as percentages of the total number of fish (excluding Clupeids) are given below for the months April, May, and June. 


$\begin{array}{lrrc} & \text { April. } & \text { May. } & \text { June. } \\ \text { G. merlangus } & 24 \cdot 7 & 17 \cdot 1 & 8 \cdot 5 \\ \text { G. minutus } & 10 \cdot 6 & 3 \cdot 9 & - \\ \text { Onos spp. } & 6 \cdot 1 & 4 \cdot 7 & 2 \cdot 2 \\ \text { S. norvegicus } & 3 \cdot 1 & 5 \cdot 0 & 7 \cdot 6 \\ \text { P. limanda } & 6 \cdot 5 & 6 \cdot 3 & 2 \cdot 2 \\ \text { P. microcephalus } & 0 \cdot 4 & 2 \cdot 3 & 2 \cdot 7 \\ \text { S. variegata } & 5 \cdot 0 & 7 \cdot 0 & 10 \cdot 7 \\ \text { C. lyra } & 29 \cdot 0 & 47 \cdot 1 & 46 \cdot 5\end{array}$

This shows that the two species of outstanding importance are Gadus merlangus and Callionymus lyra, and that the latter in May and June forms nearly half the catch of young fish. When these two species are subtracted from the remaining species of fish the spring peak in the curve in Figure 1 is largely flattened out. Yet there still remain a slightly greater number of fish in these months than in the later months. This fact, taken in conjunction with preponderance of boreal species to warmwater species shown in Table II, indicates that conditions may perhaps be regarded as slightly more favourable here for the spawning of northern fish as opposed to more southern species. It is, however, evident that this region lies very near the boundary between the two main divisions.

While in this seasonal succession almost all species show a definite seasonal periodicity in abundance, Gadus luscus and Clupea pilchardus show somewhat unorthodox habits. The young of $G$. luscus may be found in small numbers in almost any month of the year. In Table II its maximal month is given as December; this position was caused by one very large catch in December, 1927. It appears that apart from this catch the species mainly occurs between January and May. It is a fish of somewhat unusual geographical distribution, being mainly centred around the Channel, south-western and western shores of the British Isles, and the French coast in the Bay of Biscay. The above period for the occurrence of post-larvæ of $G$. luscus has been shown also by the work of Schmidt (1910) and of Chevey (1929).

Clupea pilchardus is another species which appears to have a very extended spawning period. Large numbers of pilchard eggs have been found in April, 1924 and 1925, July, 1924 and 1926, September, 1926 and 1934, October, 1932 and 1933, November 1930 and 1933, and December, 1931. It is likely, therefore, that any Clupeid occurring after the increase of sprat in February, March, and April, will be pilchard right up to the end of the year when young herring begin to appear in December.

The post-larval stages of Ammodytes also occur during many months of the year, but now that Raitt (1934) has shown the occurrence of a third species, $A$. marinus, the identification of $A$. tobianus may be wrong. 


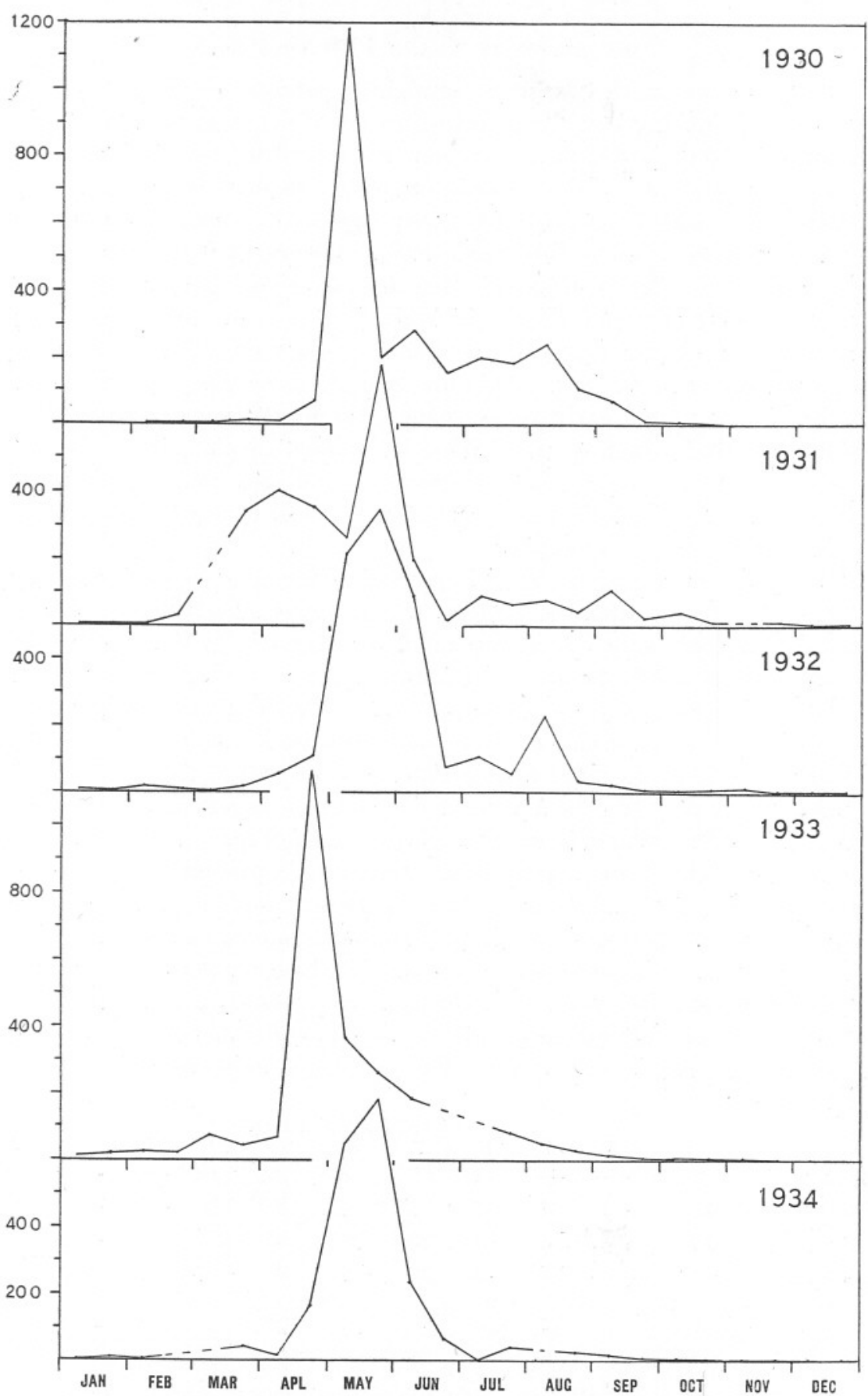

Fig. 3.-Curves showing the average catches in half-hour oblique hauls with the 2-metre ring-trawl for each fortnight for all young fish, excluding Clupeids, for each of the years 1930 to 1934 inclusive. 


\section{Comparison of Years 1930 to 1934.}

The curves for the average fortnightly catches of all young fish (excluding clupeids) have been drawn for each of the years 1930 to 1934 in Figure 3. If these five years be compared it will be seen that while in 1930, 1932 and 1934 the post-larvæ of spring spawners begin to become abundant at about the same time, they appeared comparatively earlier in 1931 and 1933. These differences between the years are worth analysing further, and in Figures 4, 5, and 6 diagrams are given showing the actual catches on each day of collection in April, May, and June for the following six species: G. merlangus, S. norvegicus, P. limanda, P. microcephalus, $S$. variegata, and $C$. lyra. All these species show the same trend of alternating late and early years, though the actual times of abundance differ slightly for each species. When the curves are compared it is seen that there is a tendency for the species to fall into three groups: (1) G. merlangus and P. limanda, (2) C. lyra and S. variegata, and (3) P. microcephalus and $S$. norvegicus.

Let us examine first the most important of the non-Clupeid teleostean food-fishes in this area, the whiting, G. merlangus. In 1930 the time of maximum abundance was in the middle of May; in 1931 they already became abundant in the middle of April and after a falling off in numbers a renewed period of abundance extended to the third week in May; in 1932 the period of maximum abundance occurred in the last fortnight of May ; in 1933 in the third week in April, and in 1934 in the first week in May. There may thus be a difference of as much as one month between the period of maximum abundance in one year and that in another.

If these differences in periods of abundance represent differences in the spawning times of the adult fish the majority of the young whiting occurring at the periods of maximum abundance should be approximately the same age. Otherwise an early peak might be composed of fish of a small size and a late peak of larger fish. Accordingly a number of fish were measured from catches made on the days on which the maximum catches occurred in each year. The results of measurement were as follows :-

\begin{tabular}{lrrrrrrrrrr} 
& \multicolumn{1}{c}{ Length in millimetres. } \\
& 4 & 5 & 6 & 7 & 8 & 9 & 10 & 11 & 12 & 13 \\
May 15, 1930 & - & - & 14 & 9 & 4 & 2 & 2 & - & - & - \\
May 25, 1932 & - & 4 & 33 & 31 & 11 & 9 & 5 & - & - & - \\
April 21, 1933 & - & 11 & 28 & 25 & 28 & 9 & 6 & 2 & - & - \\
May 2, 1934 & 1 & 8 & 12 & 20 & 15 & 6 & - & 1 & 2 & - \\
April 16, 1931 & 7 & 24 & 20 & 12 & 8 & 5 & 5 & 2 & - & - \\
May 21, 1931 & - & - & 7 & 6 & 14 & 10 & 3 & 7 & 3 & $7 *$ \\
$\quad$ * A number caught above this size on this date have been omitted as being in association \\
rith Cyanea.
\end{tabular}


OC
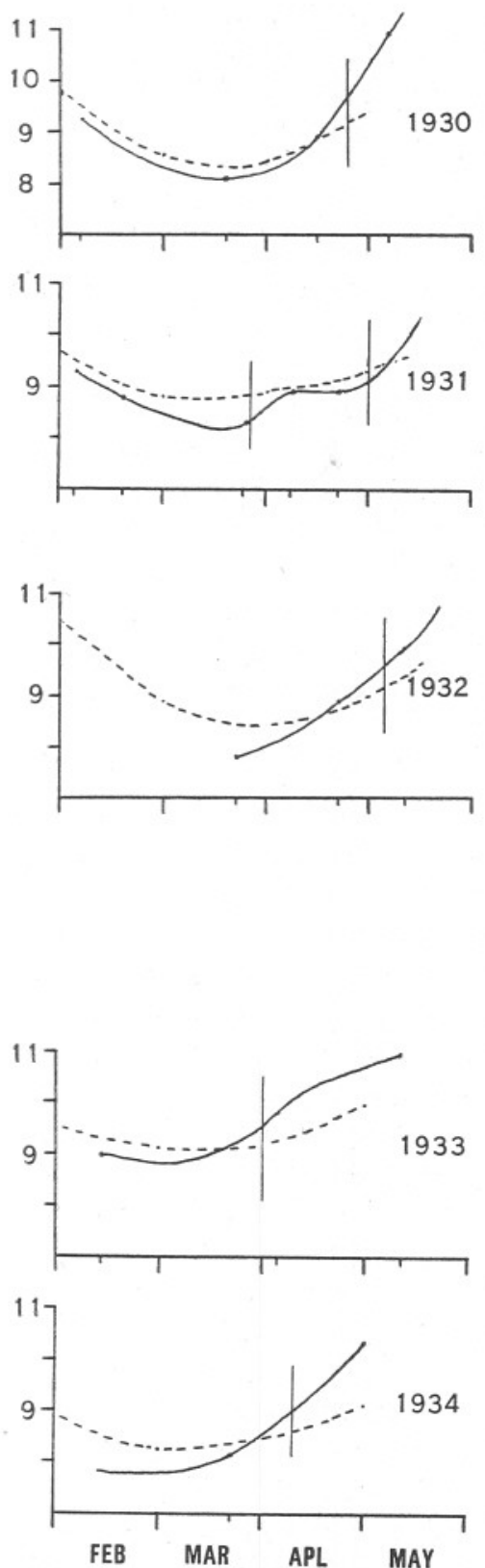

NUMBERS

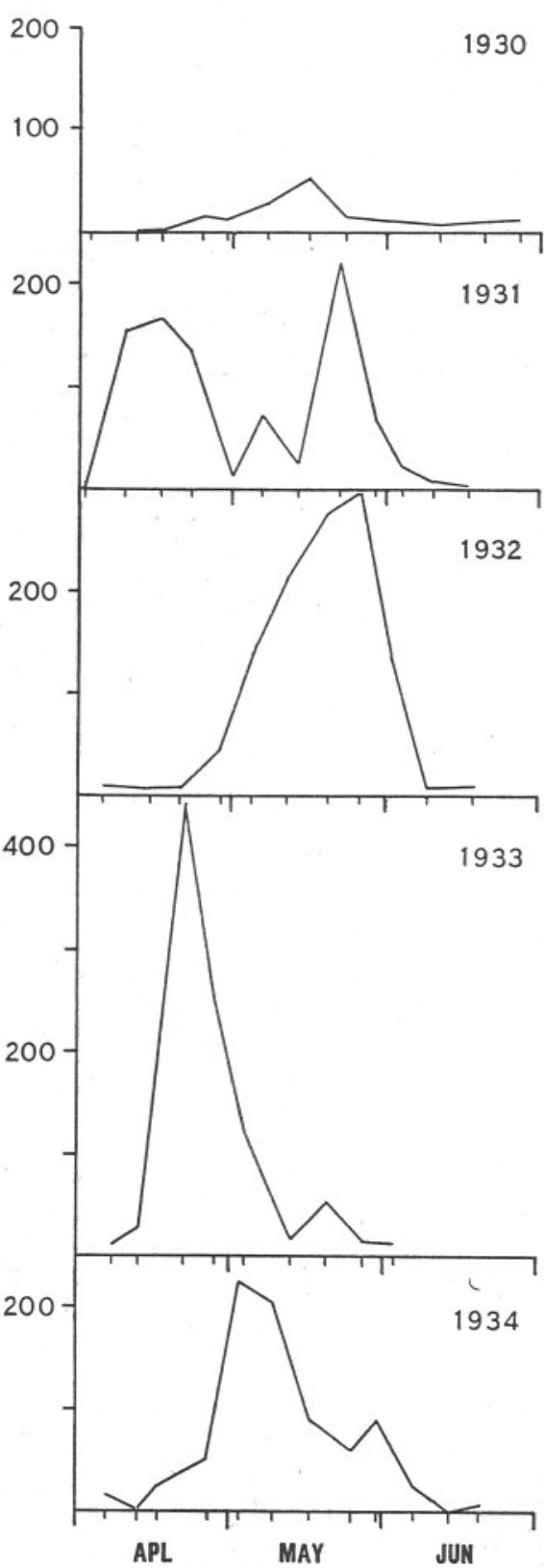

FIG. 4.-Right: Curves showing the actual catches of young whiting, G. merlangus, in half-hour oblique hauls with the 2-metre ring-trawl on each day of collection in the months April, May, and June for the years 1930 to 1934 inclusive.

Left : Temperatures in February, March, April and May for the years 1930 to 1934 inclusive. surface at L5 : _ . . - - bottom at E1. 
From these figures it can be seen that the majority of the young whiting are on the average about 6 to $8 \mathrm{~mm}$. in length at the periods of their maximum abundance in these collections. The year 1931, in which there were two peaks, has proved to be an exception in that the first peak consisted of younger and the second peak of older fish than on the average for the single peaks in the other four years.

In Figure 4, besides the curves for the abundance of young whiting, curves are given showing the temperatures of the water during the months February to May for each year. The data given are those for the surface water at L5 near the Eddystone and for the bottom water at E1 ten miles beyond. The L5 temperatures are taken from the Rapport Atlantique and data not yet published, and the E1 temperatures represent the temperatures at the beginning of each month read off from the smoothed curve and kindly supplied me by Mr. H. W. Harvey. Seeing that for the first three of these months the water is almost homogeneous from top to bottom in this area it is likely that these figures can be regarded as a very true picture of the temperature conditions. As is to be expected there is a tendency for the surface water at L5 to show a slightly greater extreme variation than the deeper offshore waters at E1.

Now Dannevig (1895, p. 149) found that the period required for the development of whiting eggs up to the point of hatching was $10 \frac{1}{4}$ days at $8^{\circ} \mathrm{C}$. and 8 days at $10^{\circ} \mathrm{C}$. Heincke and Ehrenbaum (1900, p. 253) calculated it as 13.4 days at $8.7^{\circ} \mathrm{C}$. We can assume therefore that the fish take about 10 days for their development in this region where the temperature drops to between $8^{\circ}$ and $9^{\circ} \mathrm{C}$. We do not know the rate of growth of the post-larvæ, but supposing that the majority of the postlarvæ during the peak periods were about 11 days old, this would mean that a period of three weeks had elapsed since the time of spawning. This figure is purely hypothetical, but is not likely to be very far wrong. If now we measure back a period of three weeks from the dates of maximum catches of young whiting on the curves in Figure 4 we can indicate the position of the hypothetical period of most intense spawning. These positions have been inserted as upright lines on the temperature curves in Figure 4. It is found that these lines nearly always coincide with temperatures somewhere between $9^{\circ}$ and $9.5^{\circ} \mathrm{C}$. In other words, the earliness or lateness of the peaks of maximum abundance of the postlarvæ corresponds with the times at which the temperatures are rising past $9^{\circ} \mathrm{C}$. Whether we are right in assuming that this is the temperature at which most spawning occurs, or whether it may not rather be that we have under-estimated the age of the whiting and this temperature is that which stimulates a cessation of spawning, it is evident that there is a very close correlation between the temperature conditions and the period 
SEASONAL ABUNDANCE OF YOUNG FISHES.

161
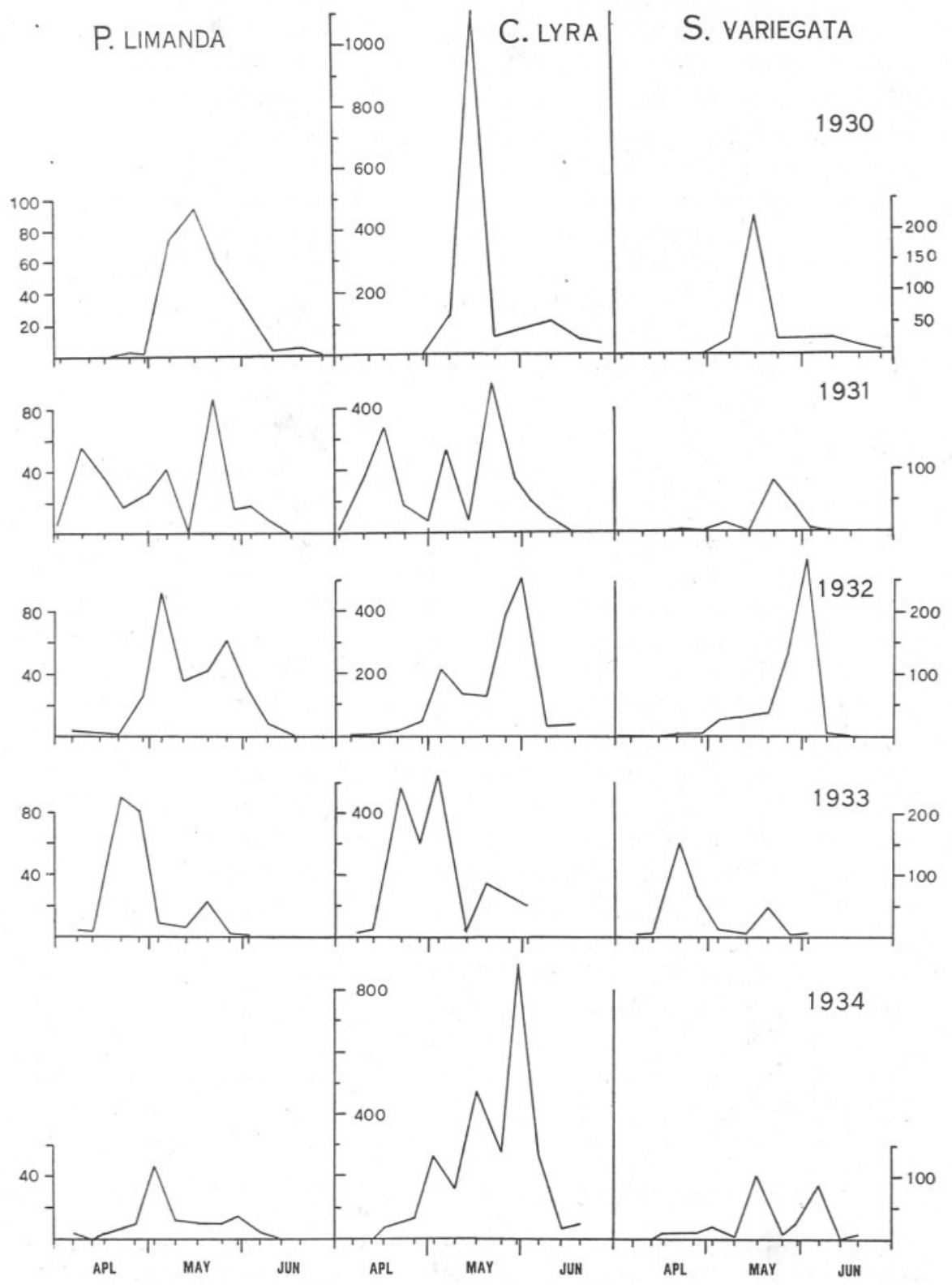

FIG. 5. -Curves showing the actual catches, in half-hour oblique hauls with the 2-metre ring-trawl, of post-larval Pleuronectes limanda, Callionymus lyra, and Sole variegate on each day of collection in the months April, May, and June for the years 1930 to 1934 inclusive. 
of maximum abundance of the young fish. This receives further confirmation from a study of the conditions in 1931. In that year there were two peaks of abundance, and although the measurements showed that they consisted of younger and older fish respectively than did the peaks in other years, it would appear that spawning was somewhat irregular and prolonged. Inspection of the temperature conditions shows that a curious state of affairs existed in April when the temperature remained stationary at about $9^{\circ} \mathrm{C}$. for two or three weeks. The upright lines coincide very nearly with this period and would do even more so were we to make allowance for the younger composition of the population at the first peak of abundance. Schmidt (1909) in his classical work on the pelagic fry of the gadoids gives the minimum temperature for spawning as $c a .5^{\circ}-6^{\circ} \mathrm{C}$. and the maximum as $c a .10^{\circ} \mathrm{C}$. Damas (1909) also gives for the North Sea that the period of maximum spawning lies during April and May at temperatures between $6^{\circ}$ and $10^{\circ} \mathrm{C}$. Off Plymouth the temperature rarely drops below $8^{\circ} \mathrm{C}$. and in some years does not drop below $9^{\circ} \mathrm{C}$., so that evidently the period available for spawning is much more restricted than in more northern regions. This fact, coupled with the above evidence that the spawning period may be advanced or retarded by as much as a month, should be a matter of considerable importance in governing the success or otherwise of each year-class. It might well be that if hatching took place much before April the post-larvæ would be requiring an abundant food supply before the spring increase in the number of small copepods takes place. Also, as is shown below on page 167, the presence of other predatory planktonic organisms in large numbers at the same time as the period of maximum abundance of postlarvæ might effectively wipe out the young of one year-class since the short spawning period would not allow the production of a further supply of fry after the predatory animals had died down in numbers.

Examination of Figures 5 and 6 shows that the five species there given show essentially a similar story to that of the young whiting. There are slight differences, but no doubt these may be correlated with the fact that the temperature optimum for spawning varies slightly with the different species.

\section{On the Changes in Abundance from Year to Year.}

Many years have passed since the reality of large fluctuations in fish populations due to the production of good year-classes was first so ably shown by Hjort and his colleagues. Yet we are still without any direct evidence as to the causes of a good survival year or the failure of a brood. As possible factors which might determine the numerical value of a new year-class $\mathrm{Hjort}$ drew attention to the following two :- 


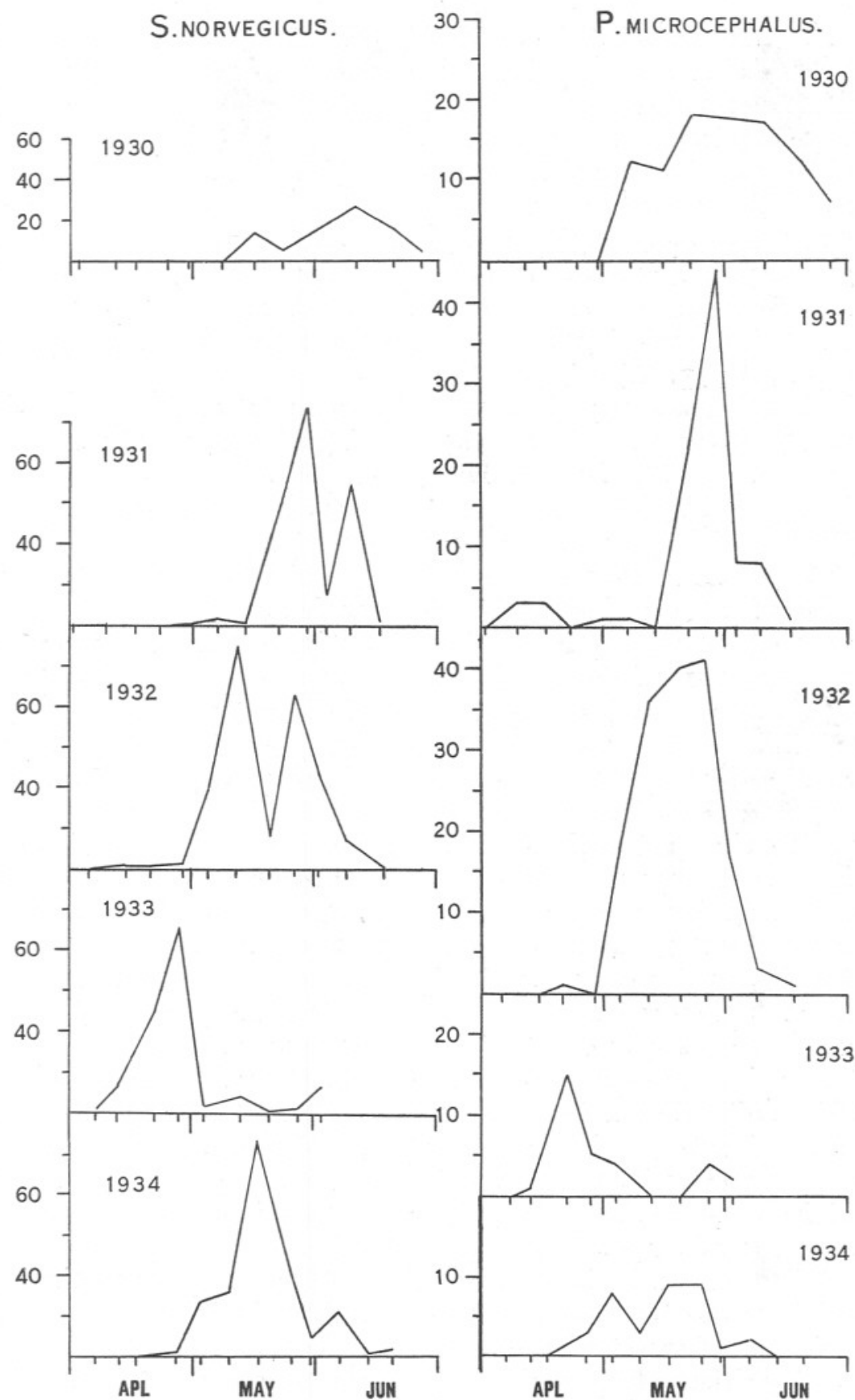

Fig. 6.-Curves showing the actual catches, in half-hour oblique hauls with the 2-metre ring-trawl, of post-larval Scophthalmus norvegicus, and Pleuronectes miorocephalus on each day of collection in the months April, May, and June for the years 1930 to 1934 inclusive.

NEW SERIES.-VOL. XX. NO. 2. AUGUST, 1935. 
1. "That those individuals which at the very moment of their being hatched did not succeed in finding the very special food they wanted would die from hunger. That in other words the origin of a rich year-class would require the contemporary hatching of the eggs and the development of the special sort of plants or nauplii which the newly hatched larva needed for its nourishment."

2. "That the young larvæ might be carried far away out over the great depths of the Norwegian Sea, where they would not be able to return and reach the bottom on the Continental shelf before the plankton in the waters died out during the autumn months of the first year of their life. (Hjort, 1926, p. 33.)

Since then other possible causes have been suggested. Einar Lea (1930, p. 100) has shown that the success of hatching of herring may depend upon the thickness of the layer of their eggs on the bottom. He had noticed during hatching experiments that the eggs in the superficial layers developed living fry while those in the deeper layers failed to hatch. On examination for this phenomenon in nature he found that in the thick flakes of eggs deposited on the bottom while nearly all eggs had been fertilised and " had commenced hatching, only the embryos in the uppermost eggs were alive and could be brought to liberate themselves. The eggs in the deeper layers, necessarily deposited earlier than the eggs in the superficial layers, contained embryos at very different stages of development, while the bottom layers were found in a state of putrefaction."

Rollefsen (1930) has shown that only slight shaking is sufficient to produce abnormal development in healthy eggs of the cod. Consequent upon the discovery in nature of large numbers of eggs with deformed embryos in the plankton he has suggested that as the cod eggs float very near the surface the breakers in heavy seas may cause considerable mortality at this early stage in the cod's development and indeed in other fish whose eggs do not have a large perivitelline space.

Heavy gales may cause damage in other ways. For instance, in January, 1933, we experienced exceptionally heavy south-westerly gales which so disturbed the bottom as apparently to dislodge great numbers of adult Gebia from their burrows (Cooper, 1933 p. 61). The sea was so churned up that it was almost milky in colour. Such exceptional seas driving on to the shores along which many of our herring spawn might cause heavy damage among the newly hatched larvæ.

A direct correlation between the rich year-classes of the Norwegian cod and the years of smallest rainfall has been shown by Sund (1924), which shows that other meterological factors must also be kept in consideration as being ultimate factors bringing about the necessary conditions in the sea for the survival of a fish brood.

In watching for fluctuations in the abundance of fish fry it is necessary 
to know what magnitude of fluctuations we are to expect. Data for such a knowledge are scanty. Thompson (1930, p. 38) says of the North Sea haddock, "In the North Sea in the recent years prior to 1928 the most numerous brood was that of 1923. Reckoned on the basis of yield in unit of fishing time this brood outnumbered that of 1922 by more than 50 to one. The other year-classes gave yields placing them at various points between these extremes of success and non-success."

Poulsen (1930, p. 26) studying the fluctuations of the abundance of cod fry in the Kattegat and Belt Sea showed in a period of six years extreme differences of as much as 77 and 31 times between abundant and poor years. He traced these fluctuations in the abundance of the different year-classes among the adult fish. Johansen (1930, p. 82), on the basis of half-hour hauls with the 2-metre ring-trawl, found that the number of post-larval herring rose from an average of 6 in 1925 to 161 in 1928 in the Sound, and similarly from 16 to 160 in the Sound and adjacent parts of the Baltic. This increase was paralleled by a similar increase in the yield of the herring fisheries. He also showed a similar correspondence between the number of fry and adults of the haddock in the Belt Sea in 1925-26 (1926). These latter two examples cannot however be regarded so much as effects of survival as of actual incursions of large numbers of spawning fish into the areas in question.

With such degrees of fluctuation in mind then let us examine the results of the young fish collections off Plymouth. Taking the years 1930 to 1934 I have given below figures showing the sum of the average monthly catches for the whole period (last column but one in Table I) divided by the corresponding figures for the best and worst years (last column in Table IV) for a number of species of fish. A column is also inserted giving the results of dividing the yearly averages of the best year by those of the worst year for the same species of fish. I have included here only those species whose yearly average shown in Table I exceeds 20 in number.

$\begin{array}{lcccc} & \begin{array}{c}\text { Best/Av. } \\ \text { year/1930-34. }\end{array} & \begin{array}{c}\text { Worst/Av. } \\ \text { year/1930-34. }\end{array} & \begin{array}{c}\text { Best/ } \\ \text { /Worst. }\end{array} & \begin{array}{c}\text { 1929/Av. } \\ \text { /1930-34. }\end{array} \\ \text { G. merlangus } & 1 \cdot 6(1932) & 0 \cdot 3(1930) & 6 \cdot 2 & 0 \cdot 50 \\ \text { G. minutus } & 3 \cdot 0(1931) * & 0 \cdot 4(1933) & 8 \cdot 3 & 0 \cdot 14 \\ \text { Onos spp. } & 2 \cdot 3(1930) & 0 \cdot 4(1932) & 5 \cdot 3 & 0 \cdot 13 \\ \text { Arnoglossus spp. } & 2 \cdot 1(1931) & 0 \cdot 2(1934) & 11 \cdot 5 & 1 \cdot 30 \\ \text { S. norvegicus } & 1 \cdot 5(1932) & 0 \cdot 4(1930) & 3 \cdot 7 & 0 \cdot 36 \\ \text { P. limanda } & 1 \cdot 5(1931) & 0 \cdot 5(1934) & 3 \cdot 4 & 0 \cdot 76 \\ \text { P. microcephalus } & 1 \cdot 8(1932) & 0 \cdot 4(1934) & 5 \cdot 1 & 0 \cdot 18 \\ \text { S. variegata } & 1 \cdot 6(1932) & 0 \cdot 4(1931) & 3 \cdot 6 & 0 \cdot 09 \\ \text { Callionymus spp. } & 1 \cdot 1(1930) & 0 \cdot 9 \cdot 1932) & 1 \cdot 2 & 0 \cdot 46 \\ \text { S. scombrus } & 2 \cdot 6(1930) & 0 \cdot 5(1933) & 5 \cdot 1 & 2 \cdot 68 \\ \text { Gobiid spp. } & 2 \cdot 8(1930) & 0 \cdot 2(1933) & 11 \cdot 9 & 2 \cdot 08\end{array}$

* This year has weighted the average for 1930-34. 
These figures show that in none of the years 1930 to 1934 did the best years exceed the average by more than three times, and the worst year with two exceptions (Arnoglossus spp. and Gobiid spp.) was never less than a quarter of the average. The third column shows that with only four exceptions the best years never exceeded the worst by more than five times. The exceptions were Gobiid spp. and Arnoglossus spp. which are summer spawners and are discussed below (p. 169); G. minutus with a maximum difference of eight times and $G$. merlangus with a difference of only six times, neither of which greatly exceed the figures for other species. In these figures there is also no indication of any marked relation between the best and worst years. In the previous report (Russell, 1930, b, p. 710) it was remarked that there was " an indication

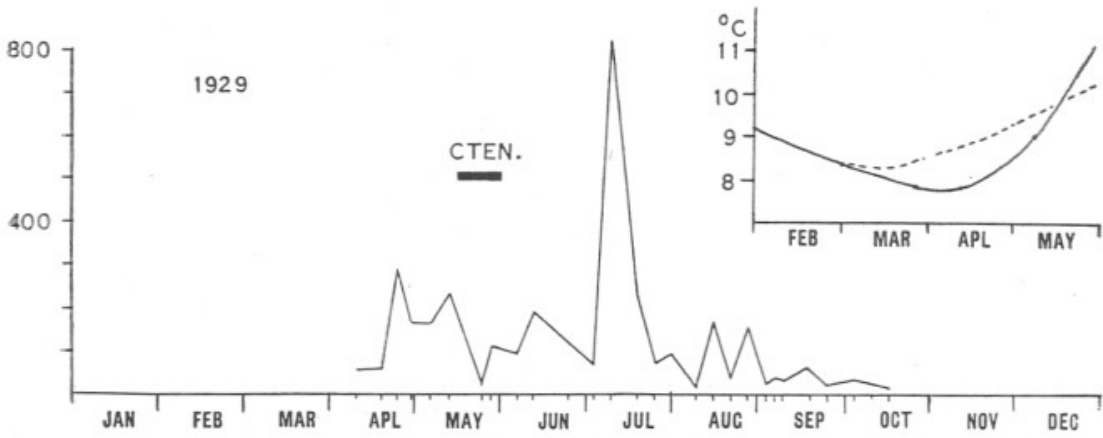

Frg. 7.-Curve showing the actual catches of all young fish, excluding Clupeids, in halfhour oblique hauls with the 2-metre ring-trawl on each day of collection in the year 1929. The temperatures for the months February to May are also given for the same year. - surface at L5 ; $-\ldots$ bottom at E1. Cren: Period during which Ctenophores were abundant.

that the post-larval stages of certain spring spawners were but poorly represented in the year 1929." Accordingly I have given above with the results for 1930 to 1934 a column showing the relation between the 1929 catches and the average for 1930 to 1934 . It shows that with three exceptions the 1929 catches fell below the average. The exceptions were Arnoglossus spp., S. scombrus, and Gobiid spp., all of which are summer spawners. It is evident therefore that conditions in 1929 had affected adversely all the remaining fish, all of which are spring spawners having their maximum abundance of post-larvæ in the months of April or May. These results are worth examining in more detail, and accordingly in Figure 7 have been plotted the total catches of young fish on each day of collection in 1929. When this figure is compared with Figure 3 the abnormal form of the curve is at once evident. The large spring peak that fell in April or May in other years is absent. There is a peak on one day in July that has been produced by young mackerel and gobies and 
these are summer spawners. In other words, the peak usually produced by the spring spawners is absent.

In Figure 7 has also been inserted a curve showing the temperature conditions in the early months of the year. If this be compared with the temperature curves given in Figure 4 it can be seen that 1929 was a late year, comparable to 1932 when a temperature of $9^{\circ} \mathrm{C}$. was only reached between the end of April and beginning of May. This being so we should have expected the spring peak in abundance to have occurred in 1929 as in 1932 towards the last week in May.

It is worthy of mention that I made the following notes when making the young fish records.

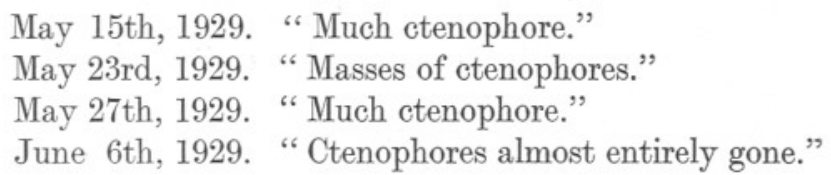

In the same year Berrill (1930, p. 753) notes a profusion of the siphonophore Stephanomia bijuga in Salcombe estuary on May 17th-19th coinciding " with a similar abundance of the three Ctenophores commonly occurring in these waters, namely Beroe cucumis Fabricius, Bolina infundibulum Fabricius and Pleurobrachea pileus Fabricius, and not only were these abundant, but they also had reached what is possibly their maximum size. Individuals of Beroe frequently were seen of at least six inches in length. Ten days later all trace of Siphonophores and Ctenophores had vanished, with the exception of some small individuals of Beroe, and these last were not seen to approach the large size already mentioned until after two months." Since that year all Ctenophores have been counted in the ring-trawl collections, and it has been found that it is usual for there to be an increase in abundance at this time of year. From the above notes it is evident, however, that in May, 1929, they must have been exceptionally abundant, and one cannot escape the possible conclusion that they may have been responsible for the absence of the peak in the abundance of young fish which should have occurred just at the same time. The voracity of Ctenophores is well known. Bigelow (1926, p. 368) has remarked that the smaller plankton animals "are locally exterminated in the centres of abundance for Pleurobrachia" and that it is common to find them packed with copepods or euphausiids, and larval fishes.

Whether this supposition be correct or not, it is at any rate certain that in May, 1929, there was some factor that affected the abundance of post-larvæ of all species of spring spawning fish indiscriminately.

During the eleven years period of observations there have only been 
two instances of excessive fluctuations in numbers of post-larvæ. In 1926 young mackerel were unusually abundant (see the 1930 report, p. 710). In that year the sum of the average monthly catches was nearly sixteen times greater than the average for the 1930-34 period. In the winter of 1932 herring larvæ were unusually abundant, the yearly average being 152 as against the next highest of 9 in 1933. Young sprat were also very abundant in March, 1931, but these were mostly newly hatched specimens.

\section{On the Change in Abundance of Post-larval Whiting.}

Although we have found no evidence of any considerable fluctuation in the abundance of post-larval whiting there are indications that a change

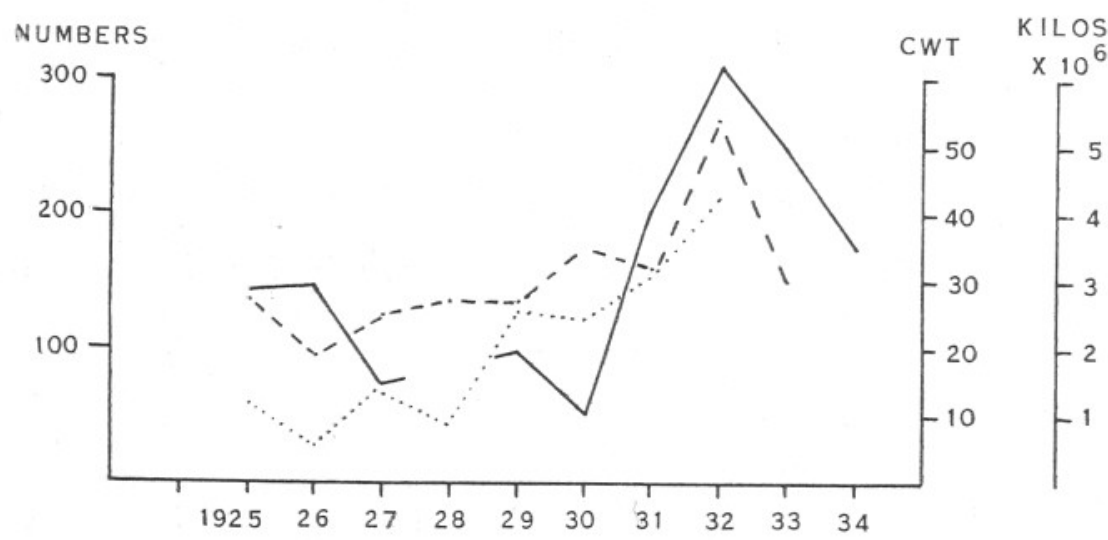

Frg. 8.-Curves showing the sums of the average monthly catches of young whiting, G. merlangus, in half-hour oblique hauls with the 2 -metre ring-trawl, for each year 1925 to 1934 (except 1928) (hours' fishing in the English Channel, area VII d-e, by British sailing trawlers $\left(---_{-}\right)$; and the total landings of whiting by French boats in the western end of the English Channel, area VII e (. . . . .).

has taken place in their numbers to a small extent during the eleven years of observation. A comparison of the results for 1930 to 1934 with those for 1924 to 1929 given in the previous report shows that on the average young whiting have been more abundant during the later period, the sum of the average monthly catches being 196 as opposed to 131 for the earlier period. Closer examination shows that the year 1930 was the culminating year of the period of low production which started in 1925 and possibly in 1924 (in which year only two samples were obtained in May and June). The sums of the average monthly catches for each year 1925 to 1934 (1928 excluded) have been plotted in the form of a graph in Figure 8. The greater abundance of young whiting in the later years is obvious. 
It is unlikely that this change in abundance is due to a shift in the spawning area. The whiting is known to spawn over a large area in the southern North Sea and Schmidt's results (1909) indicate that the postlarvæ are similarly distributed all over the English Channel.

Examination of the statistics of landings for the English Channel shows that there has apparently been a similar increase in the numbers of adult fish. In Figure 8 have also been plotted the yearly landings of whiting in cwt. per 100 hours' fishing in the English Channel (Area VII d-e) by British sailing trawlers. It is rather remarkable that this curve shows the same trend as that of the curve for abundance of the postlarvæ. In the same figure are also plotted the landings of whiting by French boats from the western English Channel (Area VII e), in this case given only as total weights landed. The same trend is again shown. In this comparison the agreement in all three curves in the peak year 1932 is striking. There thus seems to be some evidence that we are witnessing a slow change in the abundance of whiting in the English Channel, and that the increase in the number of post-larvæ is due rather to an increase in the numbers of spawning fish caused possibly by a gradual improvement in survival, than to the great success of any one year. It must be admitted that the evidence is slender, but it is at any rate sufficiently noticeable to be worthy of mention.

It is also possibly not without significance that over the same period the abundance of Callionymus post-larvæ has decreased, the sum of the monthly averages having fallen from 965 for the period 1924-29 to 547 for the period 1930-34. Next to Callionymus the whiting is the most abundant species in our spring collections, and the destruction of large numbers of the former by fine meshed trawls might produce a beneficial effect on the stock of other fish. Again the evidence is slender but is worth future attention. The abundance of Callionymus during the period 1930-34 has shown remarkable constancy, the best and worst years showing yearly averages of 500 and 582 .

\section{On the Decrease in Abundance of Summer Spawners.}

While this gradual change in the abundance of young of the above species of spring spawning fish is to be noticed, a change in the abundance of those of summer spawning fish also seems to have taken place. Examination of the curves for the fortnightly averages of total young fish for each year in Figure 3 (p. 157) shows that there has been a progressive decrease in the number of post-larvæ that occur during the months July and August. Figures are given below for the sum of the monthly average catches in each year for those species of fish whose post-larvæ 
show maximal abundance in the months June, July, August, September and October (see Table II), excluding Clupeids.

$\begin{array}{rrrrrr}1930 & . & . & . & . & 403 \\ 1931 & . & . & . & . & 230 \\ 1932 & . & . & . & . & 197 \\ 1933 & . & . & . & . & 117 \\ 1934 & . & . & . & . & 79\end{array}$

The significance of this decline in numbers is not obvious. It will be necessary to follow it up with further observations when perhaps it may be found possible to link it up with other changes that have taken place in the plankton in this area.

There is, however, one indication worthy of mention. We have already drawn attention on page 150 and Figure 2 to the greater numbers of young of summer spawners during the period 1924-29 than during the period 1930-34. Now it is natural to suppose that the potential productivity of any given water mass depends upon the amount of nutrient salts available in the water. Starting with a considerable amount of nutrient salt accumulated during the winter months we have in this area a sequence of events characterised by a heavy spring production of plankton when a large proportion of the nutrient matter available is used up, and this increase is followed by successive smaller increases during the summer months utilising the nutrient material left over after the spring increase and that which is becoming once more available due to the death of organisms earlier in the year. If by any chance the available nutrient matter at the beginning of the year should be less than usual we should expect it to show its effects on the plankton production during the summer months, since a greater proportion than usual will have been utilised by the spring increase. It is interesting to find that we can trace a possible connexion between the abundance of young of the summer spawning fish and the amount of phosphate available at the beginning of the year.

I am indebted to Dr. L. H. N. Cooper for the following figures for the maximum amount of phosphorus found in the water for the winter months in each year during the period of our observations, calculated from his own analyses and those of Dr. W. R. G. Atkins published in this Journal. 
Winter Maxima for Phosphate at E1.

Mean content of water column as mg. $\mathrm{P}$ per cubic metre corrected for salt error.

$\begin{array}{cclc}\begin{array}{c}\text { Year. } \\ 1923-24\end{array} & \text { Maximum. } & \text { Date. } & \begin{array}{c}\text { \% deviation } \\ \text { from mean. }\end{array} \\ 1924-25 & 20 \cdot 5 & \text { Jan. } 2 & +19 \\ 1925-26 & 17 \cdot 5 & \text { Dec. } 9 & \text { nil. } \\ 1926-27 & 22 & \text { Jan. } 12 & +27 \\ 1927-28 & 16 \cdot 5 & \text { Dec. } 13 & -5 \\ 1928-29 & 19 & \text { Jan. } 31 & +10 \\ 1929-30 & 17 & \text { Jan. } 2 & \text { nil. } \\ 1930-31 & - & \text { Dec. } 4 & -7 \\ 1931-32 & 16 & \text { Jan. } 28^{*} & -22 \\ 1932-33 & 13 \cdot 5 & \text { Jan. } 11 & -10 \\ 1933-34 & 15 \cdot 5 & \text { Dec. } 15 & -19 \\ \text { Mean } & 14 & & \end{array}$

The latter period of observations here stands out as a period of low phosphate content and it is the period during which the numbers of young fish were low during the summer months.

If we analyse the results for the period 1924-29 further, we obtain the following figures for summer-spawning fish (excluding Clupeids) in comparison with those given above for 1930-34.

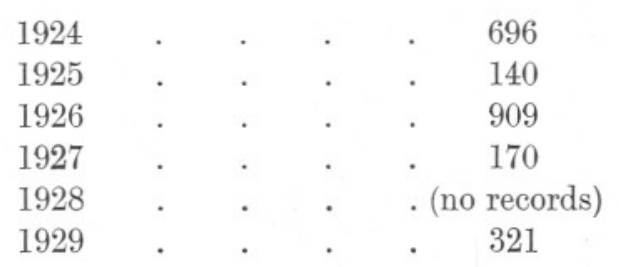

Is it significant that the two outstanding years, 1924 and 1926, were years in which the initial phosphorus content of the water was high? These two years also stand out in my memory as being years when the macroplankton in the ring-trawl collections was very abundant during the summer months and the Clupeids showed a similar abundance (see Russell, 1930, b. Table III). In these two years also it was noticeable that the post-larvæ of Molva molva were unusually abundant (see 1930 Report, p. 715). The ling is a fish which spawns over the deep waters of the Atlantic shelf and it is possible that here we have a clue to the origin of this phosphate-rich water which was evidently drawn from a different

* No data after Jan. 28th. 
source from that in other years. It is hoped later to link these changes with the occurrence of other planktonic organisms (see Russell, 1935, p. 321).

\section{SUMMARY.}

Data are given on the abundance of post-larval stages of teleostean fish in half-hour oblique hauls with the 2-metre stramin ring-trawl taken at weekly intervals at a position two miles east of the Eddystone lighthouse during the years 1930 to 1934 inclusive.

The seasonal composition of the catches is considered and it is shown that there is a gradual change over from the young of northern species of fish to those of more southern species as the summer advances. The relation between the spawning times of closely related species appears usually to be a function of their geographic distribution.

The period of maximum abundance of post-larvæ of spring-spawning fish occurs at different times in different years and this difference may be as much as a month. An apparent correlation between the times of abundance of young whiting and the previous temperature of the water has been shown.

During the period 1924 to 1934 there have been no indications of very great fluctuations in the numbers of young fish except possibly once with the mackerel and once with the herring.

There are indications that the young of the whiting have increased slightly in abundance during the last five years, and a similar increase has been shown in the landings of whiting from the English Channel. The abundance of post-larval Callionymus has correspondingly decreased. There has also been a decrease in the numbers of young of summerspawning species, and a possible connexion between their abundance and the amount of phosphate available in the water at the beginning of the year is shown.

In 1929 the normal peak of abundance of the young of spring-spawning fish was absent. There are indications that this may possibly have been caused by large numbers of Ctenophores present in the area at the time when the peak of abundance should have occurred. 


\section{REFERENCES.}

Berrill, N. J. 1930. On the Occurrence and Habits of the Siphonophore, Stephanomia bijuga (Delle Chiaje). Journ. Mar. Biol. Assoc., N.S., Vol. XVI, No. 3, pp. 753-755.

Chevey, P. 1929. Le Tacaud (Gadus luscus). Résumé de nos connaissances actuelles sur ce poisson. Rev. des Trav. Off. Pêches Marit., Tome II, Fasc. 1, pp. 73-94.

Cooper, L. H. N. 1933. Chemical Constituents of Biological Importance in the English Channel. Part III. June-December, 1932. Phosphate, Silicate, Nitrate, Hydrogen Ion Concentration, with a Comparison with Wind Records. Journ. Mar. Biol. Assoc., N.S., Vol. XIX, No. 1, pp. 55-62.

Damas, D. 1909. Contribution à la Biologie des Gadides. Cons. Perm. Int. Explor. Mer., Rapp. Proc. Verb., Vol. X, No. 3, pp. 1-277.

Dannevig, Harold. 1895. The Influence of Temperature on the Development of the Eggs of Fishes. 13th Ann. Rep. Fish. Board, Scotland, Part III, Sci. Invest., pp. 147-152.

Heincke, Fr., and Ehrenbaum, E. 1900. Eier und Larven von Fischen der deutschen Bucht. Wissensch. Meeresunter. Helgoland, N.F., Bd. 3, pp. 131-330.

Huort, Johan, and Murray, John. 1912. The Depths of the Ocean. Macmillan and Co., London.

HJort, JoHan. 1926. Fluctuations in the year-classes of important food fishes. Journ. du Conseil, Vol. I, No. 1, pp. 5-38.

Johansen, A. C. 1926. On the Remarkable Quantities of Haddock in the Belt Sea during the Winter of 1925-26, and Causes leading to the same. Journ. du Conseil, Vol. I, No. 2, pp. 140-156.

Johansen, A. C. 1930. On a correlation between the yearly catch of Herring in the Sound and the abundance of Herring Larvæ in Autumn. Cons. Perm. Int. Explor. Mer., Rapp. Proc. Verb., Vol. LXV, pp. 82-83.

Lea, Einar. 1930. Mortality in the Tribe of Norwegian Herring. Ibid., Vol. LXV, pp. 100-117.

Poulsen, Erik M. 1930. On the Fluctuations in the Abundance of Cod Fry in the Kattegat and the Belt Sea and Causes of the same. Ibid., Vol. LXV, pp. 26-30. 
Raitt, D. S. 1934. A Preliminary Account of the Sandeels of Scottish Waters. Journ. Cons. Int. Explor. Mer., Vol. IX, No. 3, pp. 365-372.

Rollefsen, Gunnar. 1930. Observations on Cod Eggs. Ibid., Vol. LXV, pp. 31-34.

Russeld, F. S. 1930, a. The Vertical Distribution of Marine Macroplankton. IX. The Pelagic Young of Teleostean Fishes in the Plymouth Area. Journ. Mar. Biol. Assoc., N.S., Vol. XVI, No. 2, pp. 639-676.

1930, b. The Seasonal Abundance and Distribution of the Pelagic Young of Teleostean Fishes Caught in the Ring-Trawl in Offshore Waters in the Plymouth Area. Ibid., Vol. XVI, No. 3, pp. 707-722. 1935. On the value of certain Plankton Animals as Indicators of Water Movements in the English Channel and North Sea. Ibid., Vol. XX, No. 2, pp. 309-332.

Sснмidt, Joнs. 1909. The Distribution of the Pelagic Fry and the Spawning Regions of the Gadoids in the North Atlantic from Iceland to Spain. Cons. Perm. Int. Explor. Mer., Vol. X, No. 4, pp. 1-229.

Sund, Oscar. 1924. Snow and the Survival of Cod Fry. Nature, No. 2831, Vol. 113, Feb. 2, pp. 163-164.

Thompson, Harold. 1930. Fluctuations in the North Sea Haddock Stock. Cons. Perm. Int. Explor. Mer., Rapp. Proc. Verb., Vol. LXV, pp. $35-44$. 
TABLE III.

Dates on which Collections were made.

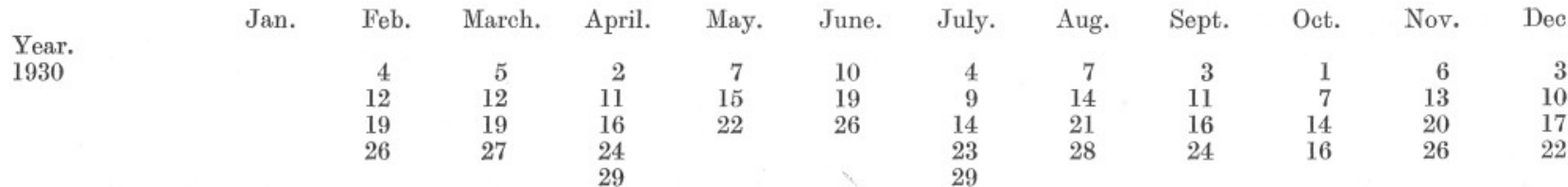

1931

$\begin{array}{rrr}1 & 6 & 17 \\ 5 & 12 & 26 \\ 15 & 20 & \\ 22 & 23 & \\ 26 & & \end{array}$

$\begin{array}{rrrrrrrrr}1 & 6 & 3 & 8 & 5 & 3 & 1 & 25 & 4 \\ 9 & 13 & 9 & 15 & 14 & 10 & 8 & & 9 \\ 16 & 21 & 16 & 23 & 21 & 17 & 15 & & 16 \\ 22 & 28 & & 30 & 28 & 24 & 22 & & 22 \\ 30 & & & & & & 29 & & 30\end{array}$

1932

$\begin{array}{rrr}7 & 3 & \\ 12 & 10 & 1 \\ 19 & 17 & 2 \\ 26 & & 3\end{array}$

$\begin{array}{rr}9 & \\ 16 & 14 \\ 23 & 2 \\ 30 & 28\end{array}$

5
14
20
28

$\begin{array}{rr}4 & 1 \\ 11 & 8 \\ 19 & 17 \\ 25 & \end{array}$

$\begin{array}{rr}5 & \\ 14 & 10 \\ 21 & 17 \\ 27 & 26\end{array}$

$\begin{array}{rr}1 & 4 \\ 7 & 11 \\ 14 & 19 \\ 21 & 26 \\ 29 & \end{array}$

14
22

1933

$\begin{array}{rrrrr}4 & 2 & 8 & 7 & 3 \\ 12 & 8 & 15 & 12 & 12 \\ 18 & 17 & 23 \dagger & 21 & 19 \\ 27 & & 30 & 27 & 26\end{array}$

2

19
27

$\begin{array}{lll}7 & 5 & 15\end{array}$

\begin{tabular}{rr}
15 & 6 \\
23 & 12 \\
\hline &
\end{tabular}

1934

$\begin{array}{rrrr}3 & 7 & 16 & 6^{*} \\ 10 & 15 & 23 & 12 \\ 19 & & 29 & 16 \\ 24 & & & 26 \\ 31 & & & \end{array}$

2
9
16
24
29

$\begin{array}{rrr}6 & 10 & 16 \\ 13 & 17 & 22 \\ 19 & 22 & 31 \\ & 30 & \end{array}$

$\begin{array}{ll}16 & \\ 22 & 13 \\ 31 & 2 \\ & 2\end{array}$

$\begin{array}{rc}6 & 3 \\ 13 & 11 \\ 21 & 18 \ddagger \\ 26 & 24 \\ & 31\end{array}$

7
15

11
24
31

* Revelstoke 4 mi. N.

$$
\text { † LA-L5. }
$$

¥ L6.

§ L3. 
TABLE IV.

\section{Average Monthly Catches of Post-larva per Half-hour Oblique Haul with 2-metre Ring-trawl.}

\begin{tabular}{|c|c|c|c|c|c|c|c|c|c|c|c|c|c|c|}
\hline & Year. & Jan. & Feb. & Iarc & pril. & May. & June. & July. & $\begin{array}{l}\text { Aug. } \\
261\end{array}$ & Sept. & Oct. & Nov. & Dec. & $\underset{1845}{\Sigma}$ \\
\hline Total Young Fish & $\begin{array}{l}1930 \\
1931 \\
1932 \\
1933 \\
1934\end{array}$ & $\begin{array}{r}28 \\
162 \\
25 \\
95\end{array}$ & $\begin{array}{r}21 \\
312 \\
405 \\
438 \\
16\end{array}$ & $\begin{array}{r}52 \\
2423 \\
193 \\
122 \\
121\end{array}$ & $\begin{array}{l}74 \\
612 \\
136 \\
660 \\
164\end{array}$ & $\begin{array}{l}897 \\
563 \\
901 \\
321 \\
796\end{array}$ & $\begin{array}{l}246 \\
168 \\
446 \\
216 \\
219\end{array}$ & $\begin{array}{r}237 \\
96 \\
96 \\
103 \\
49\end{array}$ & $\begin{array}{r}261 \\
74 \\
142 \\
37 \\
45\end{array}$ & $\begin{array}{l}52 \\
67 \\
38 \\
44 \\
14\end{array}$ & $\begin{array}{r}4 \\
43 \\
99 \\
169 \\
80\end{array}$ & $\begin{array}{l}3 \overline{2} \\
46 \\
12 \\
17\end{array}$ & $\begin{array}{r}1 \\
10 \\
4 \\
- \\
13\end{array}$ & $\begin{array}{l}1845 \\
4428 \\
2668 \\
2147 \\
1629\end{array}$ \\
\hline Ditto, less Clupeids & $\begin{array}{c}1930 \\
1931 \\
1932 \\
1933 \\
1934\end{array}$ & $\begin{array}{r}2 \\
3 \\
12 \\
7\end{array}$ & $\begin{array}{r}3 \\
16 \\
14 \\
21 \\
4\end{array}$ & $\begin{array}{r}7 \\
340 \\
11 \\
57 \\
40\end{array}$ & $\begin{array}{r}43 \\
376 \\
81 \\
618 \\
93\end{array}$ & $\begin{array}{l}854 \\
521 \\
781 \\
313 \\
728\end{array}$ & $\begin{array}{l}198 \\
136 \\
420 \\
185 \\
179\end{array}$ & $\begin{array}{r}194 \\
75 \\
83 \\
80 \\
32\end{array}$ & $\begin{array}{r}175 \\
60 \\
134 \\
36 \\
30\end{array}$ & $\begin{array}{r}41 \\
65 \\
17 \\
9 \\
12\end{array}$ & $\begin{array}{r}2 \\
19 \\
5 \\
4 \\
7\end{array}$ & $\begin{array}{r}\overline{1} \\
6 \\
2 \\
10\end{array}$ & $\begin{array}{l}\overline{4} \\
1 \\
\overline{2}\end{array}$ & $\begin{array}{l}1517 \\
1625 \\
1556 \\
1337 \\
1144\end{array}$ \\
\hline $\begin{array}{l}\text { All Clupeids spp. } \\
\text { Herring, Sprat, } \\
\text { Pilchard }\end{array}$ & $\begin{array}{l}1930 \\
1931 \\
1932 \\
1933 \\
1934\end{array}$ & $\begin{array}{r}26 \\
159 \\
13 \\
88\end{array}$ & $\begin{array}{r}18 \\
296 \\
391 \\
417 \\
12\end{array}$ & $\begin{array}{r}45 \\
2083 \\
182 \\
65 \\
81\end{array}$ & $\begin{array}{r}31 \\
236 \\
54 \\
42 \\
71\end{array}$ & $\begin{array}{r}43 \\
42 \\
120 \\
8 \\
68\end{array}$ & $\begin{array}{l}48 \\
32 \\
26 \\
31 \\
40\end{array}$ & $\begin{array}{l}43 \\
21 \\
13 \\
23 \\
17\end{array}$ & $\begin{array}{r}86 \\
14 \\
8 \\
1 \\
15\end{array}$ & $\begin{array}{r}11 \\
2 \\
21 \\
35 \\
2\end{array}$ & $\begin{array}{r}2 \\
24 \\
94 \\
165 \\
73\end{array}$ & $\begin{array}{r}- \\
21 \\
40 \\
10 \\
7\end{array}$ & $\begin{array}{r}1 \\
6 \\
3 \\
- \\
11\end{array}$ & $\begin{array}{r}328 \\
2803 \\
1111 \\
810 \\
485\end{array}$ \\
\hline $\begin{array}{l}\text { Clupea harengus } \\
\text { (with yolk-sac) } \\
\text { Herring }\end{array}$ & $\begin{array}{l}1930 \\
1931 \\
1932 \\
1933 \\
1934\end{array}$ & $\begin{array}{r}4 \\
138 \\
- \\
-\end{array}$ & $\begin{array}{l}7 \\
- \\
- \\
-\end{array}$ & $\begin{array}{r}+ \\
\overline{14} \\
1 \\
2\end{array}$ & $\begin{array}{l}- \\
- \\
- \\
-\end{array}$ & $\begin{array}{l}- \\
\overline{-} \\
\overline{-}\end{array}$ & $\begin{array}{l}- \\
\overline{-} \\
\overline{-}\end{array}$ & $\begin{array}{l}- \\
\overline{-} \\
- \\
-\end{array}$ & $\begin{array}{l}- \\
- \\
- \\
-\end{array}$ & $\begin{array}{l}- \\
\overline{-} \\
-\end{array}$ & $\begin{array}{l}- \\
- \\
- \\
-\end{array}$ & $\begin{array}{l}- \\
- \\
- \\
-\end{array}$ & $\begin{array}{l}- \\
\overline{1} \\
- \\
-\end{array}$ & $\begin{array}{r}7 \\
5 \\
152 \\
9 \\
2\end{array}$ \\
\hline $\begin{array}{l}\text { Gadus pollachius } \\
\text { Pollach }\end{array}$ & $\begin{array}{l}1930 \\
1931 \\
1932 \\
1933 \\
1934\end{array}$ & $\begin{array}{l}- \\
\overline{-} \\
-\end{array}$ & $\begin{array}{l}- \\
- \\
- \\
-\end{array}$ & $\begin{array}{l}\overline{1} \\
\overline{1} \\
-\end{array}$ & $\begin{array}{r}3 \\
+ \\
4 \\
3 \\
2\end{array}$ & $\begin{array}{r}24 \\
7 \\
16 \\
- \\
3\end{array}$ & $\begin{array}{l}\overline{1} \\
1 \\
- \\
-\end{array}$ & $\begin{array}{l}- \\
- \\
- \\
-\end{array}$ & $\begin{array}{l}- \\
\overline{-} \\
- \\
-\end{array}$ & $\begin{array}{l}- \\
- \\
-\end{array}$ & $\begin{array}{l}- \\
\overline{-} \\
\overline{-}\end{array}$ & $\begin{array}{l}- \\
\overline{-} \\
\overline{-}\end{array}$ & $\begin{array}{l}- \\
\overline{-} \\
\overline{-}\end{array}$ & $\begin{array}{r}27 \\
9 \\
21 \\
4 \\
5\end{array}$ \\
\hline $\begin{array}{l}\text { Gadus merlangus } \\
\text { Whiting }\end{array}$ & $\begin{array}{l}1930 \\
1931 \\
1932 \\
1933 \\
1934\end{array}$ & $\begin{array}{l}- \\
- \\
-\end{array}$ & $\begin{array}{l}- \\
\overline{-} \\
+ \\
-\end{array}$ & $\begin{array}{l}- \\
\overline{3} \\
2 \\
5\end{array}$ & $\begin{array}{r}6 \\
94 \\
18 \\
183 \\
25\end{array}$ & $\begin{array}{r}32 \\
97 \\
233 \\
51 \\
134\end{array}$ & $\begin{array}{r}9 \\
11 \\
52 \\
11 \\
11\end{array}$ & $\begin{array}{r}3 \\
2 \\
+ \\
1 \\
+\end{array}$ & $\begin{array}{l}- \\
\overline{2} \\
- \\
-\end{array}$ & $\begin{array}{l}- \\
- \\
- \\
-\end{array}$ & $\begin{array}{l}- \\
- \\
- \\
-\end{array}$ & $\begin{array}{l}- \\
\overline{-} \\
\bar{z}\end{array}$ & $\begin{array}{l}- \\
- \\
- \\
-\end{array}$ & $\begin{array}{r}50 \\
204 \\
308 \\
248 \\
175\end{array}$ \\
\hline $\begin{array}{l}\text { Aadus minutus } \\
\quad \text { Poor Cod or Bib }\end{array}$ & $\begin{array}{l}1930 \\
1931 \\
1932 \\
1933 \\
1934\end{array}$ & $\begin{array}{l}- \\
\overline{-}\end{array}$ & $\begin{array}{l}\overline{9} \\
- \\
- \\
-\end{array}$ & $\begin{array}{r}-\overline{1} \\
1 \\
21 \\
2\end{array}$ & $\begin{array}{l}19 \\
80 \\
10 \\
12 \\
17\end{array}$ & $\begin{array}{r}37 \\
18 \\
52 \\
1 \\
19\end{array}$ & $\begin{array}{l}+ \\
\overline{1} \\
- \\
-\end{array}$ & $\begin{array}{l}- \\
- \\
\overline{-} \\
-\end{array}$ & $\begin{array}{l}- \\
- \\
- \\
-\end{array}$ & $\begin{array}{l}- \\
- \\
- \\
-\end{array}$ & $\begin{array}{l}- \\
\overline{-} \\
- \\
-\end{array}$ & $\begin{array}{l}- \\
- \\
- \\
-\end{array}$ & $\begin{array}{l}- \\
- \\
- \\
-\end{array}$ & $\begin{array}{r}56 \\
282 \\
64 \\
34 \\
38\end{array}$ \\
\hline $\begin{array}{l}\text { Gadus luscus } \\
\text { Pouting or Pout }\end{array}$ & $\begin{array}{l}1930 \\
1931 \\
1932 \\
1933 \\
1934\end{array}$ & $\begin{array}{l}1 \\
3 \\
7 \\
4\end{array}$ & $\begin{array}{l}\overline{1} \\
8 \\
3 \\
1\end{array}$ & $\begin{array}{l}\overline{7} \\
1 \\
1 \\
2\end{array}$ & $\begin{array}{l}1 \\
4 \\
1 \\
3 \\
1\end{array}$ & $\begin{array}{r}7 \\
3 \\
4 \\
+ \\
1\end{array}$ & $\begin{array}{l}1 \\
+ \\
+ \\
-\end{array}$ & $\begin{array}{l}- \\
\overline{-} \\
\overline{1} \\
-\end{array}$ & $\begin{array}{l}1 \\
+ \\
1 \\
1 \\
1\end{array}$ & $\begin{array}{l}\dot{+} \\
+ \\
+ \\
+\end{array}$ & $\begin{array}{l}1 \\
4 \\
1 \\
2 \\
+\end{array}$ & $\begin{array}{r}-\overline{0} \\
5 \\
2 \\
2\end{array}$ & $\begin{array}{l}\overline{5} \\
1 \\
\overline{1}\end{array}$ & $\begin{array}{l}11 \\
35 \\
25 \\
20 \\
13\end{array}$ \\
\hline $\begin{array}{l}\text { Gadus callarius } \\
\text { Cod }\end{array}$ & $\begin{array}{l}1930 \\
1931 \\
1932 \\
1933 \\
1934\end{array}$ & $\begin{array}{l}- \\
\overline{-}\end{array}$ & $\begin{array}{l}- \\
\overline{-} \\
-\end{array}$ & $\begin{array}{l}- \\
\overline{-} \\
+ \\
+\end{array}$ & $\begin{array}{l}+ \\
- \\
- \\
-\end{array}$ & $\begin{array}{l}- \\
\overline{-} \\
-\end{array}$ & $\begin{array}{l}- \\
\overline{-} \\
\overline{-}\end{array}$ & $\begin{array}{l}- \\
- \\
- \\
-\end{array}$ & $\begin{array}{l}- \\
- \\
- \\
-\end{array}$ & $\begin{array}{l}- \\
- \\
- \\
-\end{array}$ & $\begin{array}{l}- \\
- \\
- \\
-\end{array}$ & $\begin{array}{l}- \\
- \\
- \\
-\end{array}$ & $\begin{array}{l}- \\
- \\
- \\
-\end{array}$ & $\begin{array}{l}+ \\
+ \\
+ \\
+\end{array}$ \\
\hline $\begin{array}{l}\text { Onos sp. } \\
\text { Rockling }\end{array}$ & $\begin{array}{l}1930 \\
1931 \\
1932 \\
1933 \\
1934\end{array}$ & $\begin{array}{l}- \\
- \\
-\end{array}$ & $\begin{array}{l}- \\
- \\
- \\
-\end{array}$ & $\begin{array}{c}- \\
3 \\
+ \\
4 \\
-\end{array}$ & $\begin{array}{r}4 \\
13 \\
1+7 \\
47 \\
9\end{array}$ & $\begin{array}{r}105 \\
8 \\
13 \\
1 \\
21\end{array}$ & $\begin{array}{l}8 \\
8 \\
2 \\
4 \\
3\end{array}$ & $\begin{array}{l}+ \\
+ \\
+ \\
+\end{array}$ & $\begin{array}{l}- \\
- \\
- \\
-\end{array}$ & $\begin{array}{l}- \\
- \\
- \\
-\end{array}$ & $\begin{array}{l}- \\
- \\
\overline{+}\end{array}$ & $\begin{array}{l}- \\
\overline{-} \\
\overline{1}\end{array}$ & $\begin{array}{l}- \\
- \\
- \\
-\end{array}$ & $\begin{array}{r}117 \\
32 \\
22 \\
57 \\
34\end{array}$ \\
\hline $\begin{array}{l}\text { Molva molva } \\
\text { Ling }\end{array}$ & $\begin{array}{l}1930 \\
1931 \\
1932 \\
1933 \\
1934\end{array}$ & $\begin{array}{l}- \\
\bar{z} \\
-\end{array}$ & $\begin{array}{l}- \\
- \\
- \\
-\end{array}$ & $\begin{array}{l}- \\
\overline{-} \\
-\end{array}$ & $\begin{array}{l}\overline{-} \\
\overline{-} \\
\overline{-}\end{array}$ & $\begin{array}{c}1 \\
1 \\
3 \\
+ \\
1\end{array}$ & $\begin{array}{l}+ \\
+ \\
2 \\
1 \\
-\end{array}$ & $\begin{array}{l}\overline{-} \\
\overline{-} \\
\overline{-}\end{array}$ & $\begin{array}{l}- \\
\overline{-} \\
\overline{-}\end{array}$ & $\begin{array}{l}- \\
\overline{-} \\
\overline{-}\end{array}$ & $\begin{array}{l}- \\
\overline{-} \\
\overline{-} \\
-\end{array}$ & $\begin{array}{l}- \\
\overline{-} \\
\overline{-}\end{array}$ & $\begin{array}{l}\overline{-} \\
\overline{-} \\
\overline{-}\end{array}$ & $\begin{array}{l}1 \\
1 \\
5 \\
1 \\
1\end{array}$ \\
\hline $\begin{array}{l}\text { Merluccius merluccius } \\
\text { Hake }\end{array}$ & $\begin{array}{l}1930 \\
1931 \\
1932 \\
1933 \\
1934\end{array}$ & $\begin{array}{l}\overline{-} \\
\overline{-}\end{array}$ & $\begin{array}{l}- \\
\overline{-} \\
- \\
-\end{array}$ & $\begin{array}{l}- \\
\overline{-} \\
\overline{-}\end{array}$ & $\begin{array}{l}\overline{-} \\
\overline{-} \\
\overline{-}\end{array}$ & $\begin{array}{l}- \\
\overline{-} \\
-\end{array}$ & $\begin{array}{l}+ \\
- \\
- \\
-\end{array}$ & $\begin{array}{l}\overline{-} \\
\overline{-} \\
\overline{-}\end{array}$ & $\begin{array}{l}+ \\
+ \\
+ \\
-\end{array}$ & $\begin{array}{l}+ \\
\overline{+} \\
\overline{-}\end{array}$ & $\begin{array}{l}\overline{-} \\
\overline{+} \\
\overline{-}\end{array}$ & $\begin{array}{l}- \\
\overline{-} \\
\overline{-}\end{array}$ & $\begin{array}{l}\overline{+} \\
\overline{-} \\
\overline{-}\end{array}$ & $\begin{array}{l}+ \\
+ \\
+ \\
-\end{array}$ \\
\hline
\end{tabular}


Year. Jan. Feb. March. April. May. June. July. Aug. Sept. Oct. Nov. Dec. $\Sigma$

\begin{tabular}{|c|c|c|c|c|c|c|c|c|c|c|c|c|c|c|}
\hline \multirow{4}{*}{$\begin{array}{l}\text { Raniceps raninus } \\
\text { Lesser Forkbeard }\end{array}$} & 1930 & & - & - & - & - & - & + & 1 & - & - & - & - & 1 \\
\hline & 1931 & - & $\overline{-}$ & - & $\overline{-}$ & - & - & - & - & 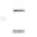 & - & - & $\overline{-}$ & $\overline{-}$ \\
\hline & $\begin{array}{l}1932 \\
1933\end{array}$ & - & - & $=$ & $\overline{-}$ & - & $\overline{-}$ & $\overline{-}$ & $\overline{-}$ & $\overline{-}$ & - & - & - & 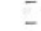 \\
\hline & 1934 & - & - & - & - & - & - & - & - & - & + & - & - & + \\
\hline \multirow{5}{*}{$\begin{array}{c}\text { Capros aper } \\
\text { Boar-flsh }\end{array}$} & 1930 & & - & - & - & - & - & 1 & 1 & + & - & - & - & 2 \\
\hline & 1931 & - & - & - & - & - & - & - & 1 & - & - & - & - & 1 \\
\hline & 1932 & - & - & - & - & - & - & - & - & + & - & - & - & + \\
\hline & 1933 & - & - & - & - & - & - & - & - & - & - & - & - & - \\
\hline & 1934 & - & - & - & - & - & - & - & - & - & - & - & - & - \\
\hline \multirow{4}{*}{$\begin{array}{l}\text { Zeus faber } \\
\text { John Dory }\end{array}$} & 1930 & & - & - & - & - & - & - & - & + & - & - & - & + \\
\hline & 1931 & - & - & - & - & - & - & - & - & - & - & - & - & - \\
\hline & 1932 & - & - & - & - & - & - & - & + & - & - & - & - & + \\
\hline & $\begin{array}{l}1933 \\
1934\end{array}$ & - & $\overline{-}$ & $\overline{-}$ & $\overline{-}$ & $\overline{-}$ & $\overline{-}$ & $=$ & 1 & + & + & $\overline{-}$ & - & 1 \\
\hline \multirow{5}{*}{$\begin{array}{l}\text { Arnoolossus sp. } \\
\text { Scaldbacks }\end{array}$} & 1930 & & - & - & - & - & 3 & 10 & 27 & 26 & + & - & - & 66 \\
\hline & 1931 & - & - & - & - & - & + & 6 & 11 & 47 & 5 & - & - & 69 \\
\hline & 1932 & - & - & - & - & - & - & 2 & 5 & 7 & 1 & - & - & 15 \\
\hline & 1933 & - & - & - & - & - & - & 2 & 6 & 3 & 1 & $\overline{-}$ & - & 12 \\
\hline & 1934 & - & - & - & - & - & + & 2 & 2 & 1 & + & 1 & - & 6 \\
\hline \multirow{5}{*}{$\begin{array}{c}\text { Rhombus lavis } \\
\text { Brill }\end{array}$} & 1930 & & - & - & - & 1 & - & - & - & - & - & - & - & 1 \\
\hline & 1931 & - & - & - & + & + & - & - & - & - & - & - & - & + \\
\hline & 1932 & - & - & - & - & - & - & + & - & + & - & - & - & + \\
\hline & 1933 & - & - & - & - & - & - & + & + & - & - & - & - & + \\
\hline & 1934 & - & - & - & - & + & + & - & - & - & - & - & - & + \\
\hline \multirow{5}{*}{$\begin{array}{l}\text { Rhombus maximus } \\
\text { Turbot }\end{array}$} & 1930 & & - & - & - & - & + & + & - & 1 & - & - & - & 1 \\
\hline & 1931 & - & - & - & - & - & + & 1 & - & - & - & - & - & 1 \\
\hline & 1932 & - & - & - & - & - & - & + & 1 & - & - & - & - & 1 \\
\hline & 1933 & - & - & - & - & - & - & 1 & 2 & + & - & - & - & 3 \\
\hline & 1934 & - & - & - & - & - & - & + & 1 & - & - & - & - & 1 \\
\hline \multirow{5}{*}{$\begin{array}{l}\text { Scophthalmus } \\
\text { norvegicus } \\
\text { Norway Topknot }\end{array}$} & 1930 & & - & - & - & 6 & 15 & 2 & - & - & - & - & - & 23 \\
\hline & 1931 & - & - & - & + & 42 & 29 & 2 & + & - & - & - & - & 73 \\
\hline & 1932 & - & - & - & 1 & 63 & 21 & + & 1 & - & - & - & - & 86 \\
\hline & 1933 & - & - & 1 & 39 & 4 & 13 & 2 & - & - & - & - & - & 60 \\
\hline & 1934 & - & - & - & 1 & 43 & 9 & 1 & - & - & - & - & - & 54 \\
\hline \multirow{5}{*}{$\begin{array}{l}\text { Zeugopterus punctatus } \\
\text { Topknot }\end{array}$} & 1930 & & - & - & - & 2 & - & - & - & - & - & - & - & 2 \\
\hline & 1931 & - & - & - & + & 4 & 1 & - & - & - & - & - & - & 5 \\
\hline & 1932 & - & - & - & + & 7 & 4 & - & - & - & - & - & - & 11 \\
\hline & 1933 & - & - & - & 7 & - & - & - & - & - & - & - & - & 7 \\
\hline & 1934 & - & - & - & 1 & 2 & + & - & - & - & - & - & - & 3 \\
\hline Pleuronectes limanda & 1930 & & - & - & 1 & 76 & 3 & - & - & - & - & - & - & 80 \\
\hline Dab & 1931 & - & - & 12 & 28 & 36 & 8 & - & - & - & - & - & - & 84 \\
\hline & 1932 & - & - & 1 & 8 & 58 & 13 & - & - & - & - & - & - & 80 \\
\hline & 1933 & - & - & 1 & 45 & 10 & 1 & - & - & - & - & - & - & 57 \\
\hline & 1934 & - & - & 2 & 4 & 18 & 1 & - & - & - & - & - & - & 25 \\
\hline Pleuronectes flesus & 1930 & & - & - & 1 & - & - & - & - & - & - & - & - & 1 \\
\hline Flounder & 1931 & - & - & 2 & 4 & 1 & - & - & - & - & - & - & - & 7 \\
\hline & 1932 & - & - & $=$ & 2 & 10 & 1 & - & - & - & - & - & - & 13 \\
\hline & 1933 & - & - & 1 & 1 & 1 & - & - & - & - & - & - & - & 3 \\
\hline & 1934 & - & - & - & + & - & - & - & - & - & - & - & - & + \\
\hline Pleuronectes & 1930 & & - & - & + & 14 & 12 & 1 & - & - & - & - & - & 27 \\
\hline microcephalus & 1931 & - & - & 3 & 1 & 17 & 6 & + & - & - & - & - & - & 27 \\
\hline Merrysole or & 1932 & - & - & - & + & 34 & 7 & - & - & - & - & - & - & 41 \\
\hline Lemon Dab & 1933 & - & - & - & 5 & 2 & 2 & - & - & - & - & - & - & 9 \\
\hline & 1934 & - & - & - & 1 & 6 & 1 & - & - & - & - & - & - & 8 \\
\hline Solea vulgaris & 1930 & & - & - & 2 & 7 & - & - & - & - & - & - & - & 9 \\
\hline Common Sole & 1931 & - & - & 3 & 6 & 2 & - & - & - & - & - & - & - & 11 \\
\hline & 1932 & - & - & + & 2 & 2 & 1 & - & - & - & - & - & - & 5 \\
\hline & 1933 & - & - & - & 1 & 1 & - & - & - & - & - & - & - & 2 \\
\hline & 1934 & - & - & + & 1 & + & - & - & - & - & - & - & - & 1 \\
\hline Solea variegata & 1930 & & - & - & - & 90 & 13 & 3 & 1 & - & - & - & - & 107 \\
\hline Thickback & 1931 & - & - & - & + & 33 & 1 & 1 & 1 & - & - & - & - & 36 \\
\hline & 1932 & - & - & - & 2 & 56 & 71 & 1 & + & - & - & - & - & 130 \\
\hline & 1933 & - & - & 1 & 56 & 17 & 6 & - & - & - & - & - & - & 80 \\
\hline & 1934 & - & - & + & 5 & 31 & 30 & 1 & - & - & - & - & - & 67 \\
\hline Solea lascaris & 1930 & & - & - & - & - & - & - & - & + & + & - & - & + \\
\hline Sand Sole & 1931 & - & - & - & - & - & - & - & - & - & - & - & - & \\
\hline & 1932 & - & - & - & - & - & - & - & + & + & - & - & - & + \\
\hline & 1933 & - & - & - & - & - & - & - & - & - & - & - & - & \\
\hline & 1934 & - & - & - & - & - & - & + & - & - & - & - & - & + \\
\hline
\end{tabular}


Year. Jan. Feb. March. April. May. June. July. Aug. Sept. Oct. Nov. Dec. $\Sigma$

\begin{tabular}{|c|c|c|c|c|c|c|c|c|c|c|c|c|c|}
\hline $\begin{array}{l}\text { Serranus cabrilla } \\
\text { Sea Perch }\end{array}$ & $\begin{array}{l}1930 \\
1931 \\
1932 \\
1933 \\
1934\end{array}$ & $\begin{array}{l}- \\
- \\
-\end{array}$ & $\begin{array}{l}- \\
\overline{-} \\
\overline{-}\end{array}$ & $\begin{array}{l}- \\
\overline{-} \\
\overline{-}\end{array}$ & $\begin{array}{l}\overline{-} \\
\bar{z} \\
\overline{-}\end{array}$ & $\begin{array}{l}\bar{z} \\
\bar{z} \\
\overline{-}\end{array}$ & $\begin{array}{l}\bar{z} \\
\bar{z} \\
-\end{array}$ & $\begin{array}{l}\bar{z} \\
\bar{z} \\
\overline{-}\end{array}$ & $\begin{array}{r}\overline{1} \\
+ \\
1 \\
-\end{array}$ & $\begin{array}{r}1 \\
+ \\
2 \\
+ \\
-\end{array}$ & $\begin{array}{l}\overline{-} \\
\overline{-} \\
\overline{-}\end{array}$ & $\begin{array}{l}\overline{-} \\
\bar{z} \\
\overline{-}\end{array}$ & $\begin{array}{l}\bar{z} \\
\bar{z} \\
\overline{-}\end{array}$ \\
\hline $\begin{array}{l}\text { Caranx trachurus } \\
\text { Horse Mackerel } \\
\text { or Scad }\end{array}$ & $\begin{array}{l}1930 \\
1931 \\
1932 \\
1933 \\
1934\end{array}$ & $\begin{array}{l}- \\
\overline{-}\end{array}$ & $\begin{array}{l}\overline{-} \\
\overline{-} \\
\overline{-}\end{array}$ & $\begin{array}{l}- \\
\overline{-} \\
\overline{-}\end{array}$ & $\begin{array}{l}- \\
\overline{-} \\
\overline{-}\end{array}$ & $\begin{array}{l}- \\
- \\
- \\
-\end{array}$ & $\begin{array}{l}- \\
- \\
- \\
-\end{array}$ & $\begin{array}{r}1 \\
1 \\
+ \\
3 \\
1\end{array}$ & $\begin{array}{r}17 \\
4 \\
6 \\
8 \\
3\end{array}$ & $\begin{array}{l}7 \\
6 \\
1 \\
1 \\
9^{*}\end{array}$ & $\begin{array}{l}+ \\
+ \\
- \\
-\end{array}$ & $\begin{array}{l}- \\
\bar{z} \\
\overline{-}\end{array}$ & $\begin{array}{l}- \\
\bar{z} \\
\overline{-}\end{array}$ \\
\hline $\begin{array}{l}\text { Mullus surmuletus } \\
\text { Red Mullet }\end{array}$ & $\begin{array}{l}1930 \\
1931 \\
1932 \\
1933 \\
1934\end{array}$ & $\begin{array}{l}- \\
\overline{-} \\
-\end{array}$ & $\begin{array}{l}\overline{-} \\
\overline{-} \\
-\end{array}$ & $\begin{array}{l}- \\
\overline{-} \\
\overline{-}\end{array}$ & $\begin{array}{l}\bar{z} \\
\bar{z} \\
\overline{-}\end{array}$ & $\begin{array}{l}\overline{-} \\
\overline{-} \\
\overline{-}\end{array}$ & $\begin{array}{l}\overline{-} \\
\overline{-} \\
\overline{-}\end{array}$ & $\begin{array}{l}+ \\
- \\
-\end{array}$ & $\begin{array}{l}\overline{-} \\
\overline{+} \\
\overline{-}\end{array}$ & $\begin{array}{l}- \\
\overline{-} \\
\overline{-}\end{array}$ & $\begin{array}{l}\bar{z} \\
\overline{-} \\
\overline{-}\end{array}$ & $\begin{array}{l}\overline{-} \\
\overline{-} \\
\overline{-}\end{array}$ & $\begin{array}{l}- \\
\bar{z} \\
\overline{-}\end{array}$ \\
\hline $\begin{array}{l}\text { Morone labrax } \\
\text { Bass }\end{array}$ & $\begin{array}{l}1930 \\
1931 \\
1932 \\
1933 \\
1934\end{array}$ & $\begin{array}{l}- \\
\overline{-} \\
-\end{array}$ & $\begin{array}{l}\overline{-} \\
\overline{-}\end{array}$ & $\begin{array}{l}\overline{1} \\
- \\
- \\
-\end{array}$ & $\begin{array}{l}+ \\
+ \\
+\end{array}$ & $\begin{array}{l}+ \\
\overline{-} \\
\overline{-}\end{array}$ & $\begin{array}{l}\overline{-} \\
\overline{-} \\
\overline{-}\end{array}$ & $\begin{array}{l}\bar{z} \\
\overline{-}\end{array}$ & $\begin{array}{l}\bar{z} \\
\overline{-} \\
\overline{-}\end{array}$ & $\begin{array}{l}\overline{-} \\
\overline{-} \\
\overline{-}\end{array}$ & $\begin{array}{l}- \\
\overline{-} \\
\overline{-}\end{array}$ & $\begin{array}{l}- \\
- \\
- \\
-\end{array}$ & $\begin{array}{l}- \\
\overline{-} \\
-\end{array}$ \\
\hline $\begin{array}{l}\text { Ammodytes? tobianus } \\
\text { Lesser Sandeel }\end{array}$ & $\begin{array}{l}1930 \\
1931 \\
1932 \\
1933 \\
1934\end{array}$ & $\begin{array}{l}1 \\
1 \\
5 \\
-\end{array}$ & $\begin{array}{r}1 \\
1 \\
5 \\
12 \\
-\end{array}$ & $\begin{array}{r}2 \\
58 \\
3 \\
18 \\
15\end{array}$ & $\begin{array}{r}+ \\
5 \\
1 \\
1 \\
1\end{array}$ & $\begin{array}{l}\overline{1} \\
\overline{-} \\
-\end{array}$ & $\begin{array}{l}\overline{+} \\
\overline{-} \\
-\end{array}$ & $\begin{array}{l}\overline{1} \\
- \\
\overline{+}\end{array}$ & $\begin{array}{l}- \\
\overline{-} \\
+ \\
+\end{array}$ & $\begin{array}{l}\dot{+} \\
+ \\
\dot{+} \\
-\end{array}$ & $\begin{array}{l}\frac{-}{1} \\
+ \\
1\end{array}$ & $\begin{array}{l}- \\
- \\
-\end{array}$ & + \\
\hline $\begin{array}{l}\text { Ammodytes lanceolatus } \\
\text { Greater Sandeel }\end{array}$ & $\begin{array}{l}1930 \\
1931 \\
1932 \\
1933 \\
1934\end{array}$ & $\begin{array}{l}- \\
\overline{2}\end{array}$ & $\begin{array}{l}- \\
\overline{-} \\
\overline{2}\end{array}$ & $\begin{array}{l}2 \\
- \\
-\end{array}$ & $\begin{array}{r}- \\
\overline{8} \\
11 \\
+\end{array}$ & $\begin{array}{r}1 \\
9 \\
13 \\
1 \\
23\end{array}$ & $\begin{array}{l}2 \\
4 \\
6 \\
5 \\
1\end{array}$ & $\begin{array}{l}3 \\
4 \\
2 \\
2 \\
1\end{array}$ & $\begin{array}{r}14 \\
2 \\
4 \\
+ \\
2\end{array}$ & $\begin{array}{l}+ \\
1 \\
+ \\
- \\
-\end{array}$ & $\begin{array}{l}\overline{-} \\
\overline{1}\end{array}$ & $\begin{array}{l}- \\
- \\
- \\
-\end{array}$ & $\begin{array}{l}- \\
\overline{-} \\
\overline{-}\end{array}$ \\
\hline $\begin{array}{l}\text { Cepola rubescens } \\
\text { Red Band Fish }\end{array}$ & $\begin{array}{l}1930 \\
1931 \\
1932 \\
1933 \\
1934\end{array}$ & $\begin{array}{l}- \\
\overline{-} \\
-\end{array}$ & $\begin{array}{l}\overline{-} \\
\overline{-} \\
\bar{z}\end{array}$ & $\begin{array}{l}\overline{-} \\
\overline{-} \\
\bar{z}\end{array}$ & $\begin{array}{l}- \\
\overline{-} \\
\overline{-}\end{array}$ & $\begin{array}{l}- \\
\overline{-} \\
\overline{-}\end{array}$ & $\begin{array}{l}\overline{-} \\
\overline{-} \\
\overline{-}\end{array}$ & $\begin{array}{l}\overline{-} \\
\overline{-}\end{array}$ & $\begin{array}{l}+ \\
1 \\
- \\
-\end{array}$ & $\begin{array}{l}- \\
\overline{+} \\
\overline{-}\end{array}$ & $\begin{array}{l}\overline{-} \\
\overline{-} \\
\overline{-}\end{array}$ & $\begin{array}{l}\overline{-} \\
\overline{-} \\
\overline{-}\end{array}$ & $\begin{array}{l}- \\
\bar{z} \\
\overline{-}\end{array}$ \\
\hline $\begin{array}{l}\text { Callionymus snp. } \\
\text { Dragonets }\end{array}$ & $\begin{array}{l}1930 \\
1931 \\
1932 \\
1933 \\
1934\end{array}$ & $\begin{array}{l}- \\
- \\
-\end{array}$ & $\begin{array}{l}\overline{+} \\
- \\
-\end{array}$ & $\begin{array}{r}- \\
50 \\
+ \\
5 \\
-\end{array}$ & $\begin{array}{r}2 \\
129 \\
18 \\
206 \\
26\end{array}$ & $\begin{array}{l}431 \\
240 \\
215 \\
211 \\
410\end{array}$ & $\begin{array}{r}65 \\
48 \\
191 \\
102 \\
112\end{array}$ & $\begin{array}{r}59 \\
9 \\
15 \\
44 \\
12\end{array}$ & $\begin{array}{r}23 \\
17 \\
59 \\
5 \\
6\end{array}$ & $\begin{array}{r}2 \\
5 \\
1 \\
1 \\
+\end{array}$ & $\begin{array}{l}\overline{9} \\
1 \\
1 \\
2\end{array}$ & $\begin{array}{l}\overline{1} \\
\overline{-} \\
\overline{6}\end{array}$ & $\begin{array}{l}- \\
\overline{-} \\
\overline{1}\end{array}$ \\
\hline $\begin{array}{l}\text { Labrus beraylta } \\
\text { Ballan Wrasse }\end{array}$ & $\begin{array}{l}1930 \\
1931 \\
1932 \\
1933 \\
1934\end{array}$ & $\begin{array}{l}- \\
-\end{array}$ & $\begin{array}{l}- \\
- \\
- \\
-\end{array}$ & $\begin{array}{l}- \\
- \\
-\end{array}$ & $\begin{array}{l}- \\
\overline{-} \\
- \\
-\end{array}$ & $\begin{array}{c}\overline{1} \\
+ \\
\overline{2}\end{array}$ & $\begin{array}{l}1 \\
2 \\
4 \\
5 \\
-\end{array}$ & $\begin{array}{l}+ \\
\overline{2} \\
- \\
-\end{array}$ & $\begin{array}{l}- \\
- \\
- \\
-\end{array}$ & $\begin{array}{l}- \\
\overline{-} \\
-\end{array}$ & $\begin{array}{l}- \\
\overline{-} \\
\overline{-}\end{array}$ & $\begin{array}{l}- \\
- \\
- \\
-\end{array}$ & $\begin{array}{l}- \\
- \\
-\end{array}$ \\
\hline $\begin{array}{l}\text { Labrus mixtus } \\
\text { Cuckoo Wrasse }\end{array}$ & $\begin{array}{l}1930 \\
1931 \\
1932 \\
1933 \\
1934\end{array}$ & $\begin{array}{l}- \\
\overline{-} \\
-\end{array}$ & $\begin{array}{l}- \\
- \\
- \\
-\end{array}$ & $\begin{array}{l}- \\
- \\
- \\
-\end{array}$ & $\begin{array}{l}- \\
- \\
- \\
-\end{array}$ & $\begin{array}{l}\overline{+} \\
\overline{-} \\
-\end{array}$ & $\begin{array}{l}2 \\
- \\
1 \\
-\end{array}$ & $\begin{array}{l}- \\
- \\
- \\
-\end{array}$ & $\begin{array}{l}- \\
\overline{-} \\
- \\
-\end{array}$ & $\begin{array}{l}- \\
\overline{-} \\
\overline{-}\end{array}$ & $\begin{array}{l}- \\
\overline{-} \\
\overline{-}\end{array}$ & $\begin{array}{l}- \\
- \\
- \\
-\end{array}$ & $\begin{array}{l}- \\
\overline{-} \\
-\end{array}$ \\
\hline Ctenolabrus rupestris & $\begin{array}{l}1930 \\
1931 \\
1932 \\
1933 \\
1934\end{array}$ & $\begin{array}{l}- \\
\overline{-}\end{array}$ & $\begin{array}{l}\overline{-} \\
\overline{-} \\
\overline{-}\end{array}$ & $\begin{array}{l}\overline{-} \\
\overline{-} \\
-\end{array}$ & $\begin{array}{l}\overline{-} \\
\bar{z} \\
\overline{-}\end{array}$ & $\begin{array}{l}\overline{-} \\
\overline{-} \\
\overline{-}\end{array}$ & $\begin{array}{l}2 \\
\overline{1} \\
-\end{array}$ & $\begin{array}{r}27 \\
7 \\
10 \\
1 \\
1\end{array}$ & $\begin{array}{r}15 \\
1 \\
2 \\
- \\
+\end{array}$ & $\begin{array}{l}\frac{1}{-} \\
+ \\
- \\
-\end{array}$ & $\begin{array}{l}\bar{z} \\
\overline{-} \\
\overline{-}\end{array}$ & $\begin{array}{l}- \\
\overline{-} \\
\overline{-}\end{array}$ & $\begin{array}{l}- \\
\bar{z} \\
\overline{-}\end{array}$ \\
\hline Crenilabrus melops & $\begin{array}{l}1930 \\
1931 \\
1932 \\
1933 \\
1934\end{array}$ & $\begin{array}{l}- \\
- \\
-\end{array}$ & $\begin{array}{l}- \\
\overline{-} \\
\bar{z}\end{array}$ & $\begin{array}{l}- \\
\overline{-} \\
\overline{-}\end{array}$ & $\begin{array}{l}- \\
- \\
- \\
-\end{array}$ & $\begin{array}{l}- \\
- \\
- \\
-\end{array}$ & $\begin{array}{l}1 \\
1 \\
- \\
+\end{array}$ & $\begin{array}{c}2 \\
1 \\
+ \\
- \\
-\end{array}$ & $\begin{array}{l}+ \\
+ \\
- \\
+\end{array}$ & $\begin{array}{l}- \\
- \\
- \\
-\end{array}$ & $\begin{array}{l}- \\
\overline{-} \\
\overline{-}\end{array}$ & $\begin{array}{l}- \\
- \\
- \\
-\end{array}$ & $\begin{array}{l}- \\
- \\
-\end{array}$ \\
\hline Centrolabrus exoletus & $\begin{array}{l}1930 \\
1931 \\
1932 \\
1933 \\
1934\end{array}$ & $\begin{array}{l}- \\
- \\
-\end{array}$ & $\begin{array}{l}- \\
- \\
- \\
-\end{array}$ & $\begin{array}{l}- \\
- \\
- \\
-\end{array}$ & $\begin{array}{l}- \\
- \\
- \\
-\end{array}$ & $\begin{array}{l}- \\
\overline{-} \\
\overline{-}\end{array}$ & $\begin{array}{l}- \\
- \\
- \\
-\end{array}$ & $\begin{array}{l}2 \\
1 \\
3 \\
- \\
-\end{array}$ & $\begin{array}{l}+ \\
\overline{1} \\
- \\
-\end{array}$ & $\begin{array}{l}- \\
- \\
- \\
-\end{array}$ & $\begin{array}{l}- \\
\bar{z} \\
\overline{-}\end{array}$ & $\begin{array}{l}- \\
- \\
-\end{array}$ & $\begin{array}{l}- \\
- \\
-\end{array}$ \\
\hline $\begin{array}{l}\text { Trachinus vipera } \\
\text { Lesser Weever }\end{array}$ & $\begin{array}{l}1930 \\
1931 \\
1932 \\
1933 \\
1934\end{array}$ & $\begin{array}{l}- \\
\overline{-}\end{array}$ & $\begin{array}{l}\overline{-} \\
\overline{-} \\
\overline{-}\end{array}$ & $\begin{array}{l}\overline{-} \\
\overline{-} \\
\overline{-}\end{array}$ & $\begin{array}{l}- \\
\overline{-} \\
\overline{-}\end{array}$ & $\begin{array}{l}\overline{-} \\
\overline{-} \\
\overline{-}\end{array}$ & $\begin{array}{l}- \\
\overline{-} \\
\overline{-}\end{array}$ & $\begin{array}{l}2 \\
4 \\
2 \\
4 \\
1\end{array}$ & $\begin{array}{l}7 \\
4 \\
4 \\
2 \\
2\end{array}$ & $\begin{array}{l}1 \\
+ \\
+ \\
-\end{array}$ & $\begin{array}{l}\overline{-} \\
\bar{z} \\
\bar{z}\end{array}$ & $\begin{array}{l}- \\
\overline{-} \\
\overline{-}\end{array}$ & $\begin{array}{l}- \\
\overline{-} \\
\overline{-}\end{array}$ \\
\hline
\end{tabular}


Year. Jan. Feb. March. April. May. June. July. Aug. Sept. Oct. Nov. Dec. $\Sigma$

Trachinus draco

1932 August 26th, 2 Greater Weever

Scomber scombrus Mackerel

Gobius spp.

Gobies

Lebetus scorpioides

Blennius pholis Shanny

Blennius ocellaris
Butterfly Blenny

$$
1930
$$

1931

1932

1934

1930
1931
1932

1932

1933

1930

1931

1932

1934

1930

1932

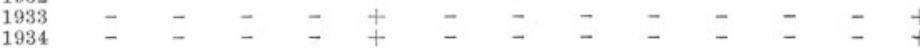

1930

1931

1933

1934

Blennius gattorugine

Tompot

1930

1932

1934

Chirolophis galerit

Yarrell's Blenny

1930

193

1931
1932
1933

1933 Agonus cataphractus
Pogge

1930

1931

1933

1934

$\begin{array}{rrrrrrrr}\text { Trigla spp. } & 1930 & & - & - & + & 13 & 3 \\ \text { Grey and Red } & 1931 & - & - & - & 3 & 3 & 1 \\ \text { Gurnards, and Tub } 1932 & - & - & - & - & 2 & 6 \\ & 1933 & - & - & - & 2 & 4 & 4 \\ 1934 & - & - & - & - & 1 & 2\end{array}$

$\begin{array}{cc}\text { Cottus bubalis } & 1930 \\ \text { Father Lasher } & 1931 \\ & 1932 \\ & 1933 \\ & 1934 \\ & 1930 \\ \text { Liparis montagui } & 1931 \\ \text { Montague's Sucker } & 1932 \\ & 1933 \\ & 1934 \\ \text { Lepadogaster } & 1930 \\ \text { bimaculatus } & 1931 \\ \text { Doubly Spotted } & 1932 \\ \text { Sucker } & 1933 \\ & 1934 \\ \text { Lophius piscatorius } & 1930 \\ \text { Angler } & 1931 \\ & 1932 \\ & 1933 \\ & 1934\end{array}$

NEW SERIES.-VOL. XX. NO. 2. AUGUST, 1935. 
